\title{
Land constraints in Kenya's densely populated rural areas: implications for food policy and institutional reform
}

\author{
T. S. Jayne • Milu Muyanga
}

Received: 9 December 2011 / Accepted: 15 February 2012 /Published online: 20 March 2012

(C) The Author(s) 2012. This article is published with open access at Springerlink.com

\begin{abstract}
This study analyzes the impact of increasing population density in Kenya's rural areas on smallholder behavior and welfare indicators. We first present evidence to explain how land constraints can be emerging within an overall context of apparent land under-utilization. Using data from five panel surveys on 1,146 small-scale farms over the 1997-2010 period, we use econometric techniques to determine how increasing rural population density is affecting farm household behavior and livelihoods. We find that farm productivity and incomes tend to rise with population density up to 600 650 persons per $\mathrm{km}^{2}$; beyond this threshold, rising population density is associated with sharp declines in farm productivity, total household income, and asset wealth. Currently $14 \%$ of Kenya's rural population resides in areas exceeding this population density. The study concludes by exploring the nature of institutional and policy reforms needed to address these development problems.
\end{abstract}

T. S. Jayne $(\bowtie) \cdot$ M. Muyanga

Department of Agricultural, Food, and Resource Economics, Michigan State University, c/o 207 Agriculture Hall,

East Lansing, MI 48824-1039, USA

e-mail: jayne@msu.edu

M. Muyanga

Tegemeo Institute, Egerton University,

Nakuru, Kenya

Present Address:

T. S. Jayne

Indaba Agricultural Policy Research Institute,

Lusaka, Zambia
Keywords Land $\cdot$ Population density · Smallholder agriculture $\cdot$ Food security $\cdot$ Policy $\cdot$ Kenya

\section{Introduction}

Land has been commonly considered an abundant resource in Sub-Saharan Africa (Deininger et al. 2011). However, nationally representative farm surveys consistently paint a contrasting picture with the following empirical regularities: First, half or more of Africa's smallholder farms are below 1.5 ha in size with limited or no potential for area expansion (Jayne et al. 2003). Second, a high proportion of farmers perceive that it is not possible for them to acquire more land through customary land allocation procedures, even in areas where a significant portion of land appears to be unutilized (Stambuli 2002; Jayne et al. 2009). Third, in some areas such as Kenya, roughly a quarter of young men and women start their families without inheriting any land from their parents, forcing them either to commit themselves to off-farm employment or buy land from an increasingly active land sales market (Yamano et al. 2009)

Evidence now indicates that a substantial proportion of Africa's rural population lives in relatively densely populated areas. For example, over half of Kenya's rural population lives in areas exceeding 250 persons per square kilometre (Fig. 1). Data from Columbia University's Global Rural-urban Mapping Project indicate that the proportion of the rural population living in areas exceeding 250 persons per $\mathrm{km}^{2}$ is of similar or greater magnitude in Nigeria, Rwanda, Burundi, Uganda, and Malawi, which together with Kenya account for roughly 35\% of sub-Saharan Africa's total population. Moreover, the effects of increasingly crowded rural areas are not confined to those living in such areas. Hence, the question of appropriate development strategies for densely populated rural areas is increasingly relevant to a significant portion of Africa's population. 
Fig 1 Population density in Kenya

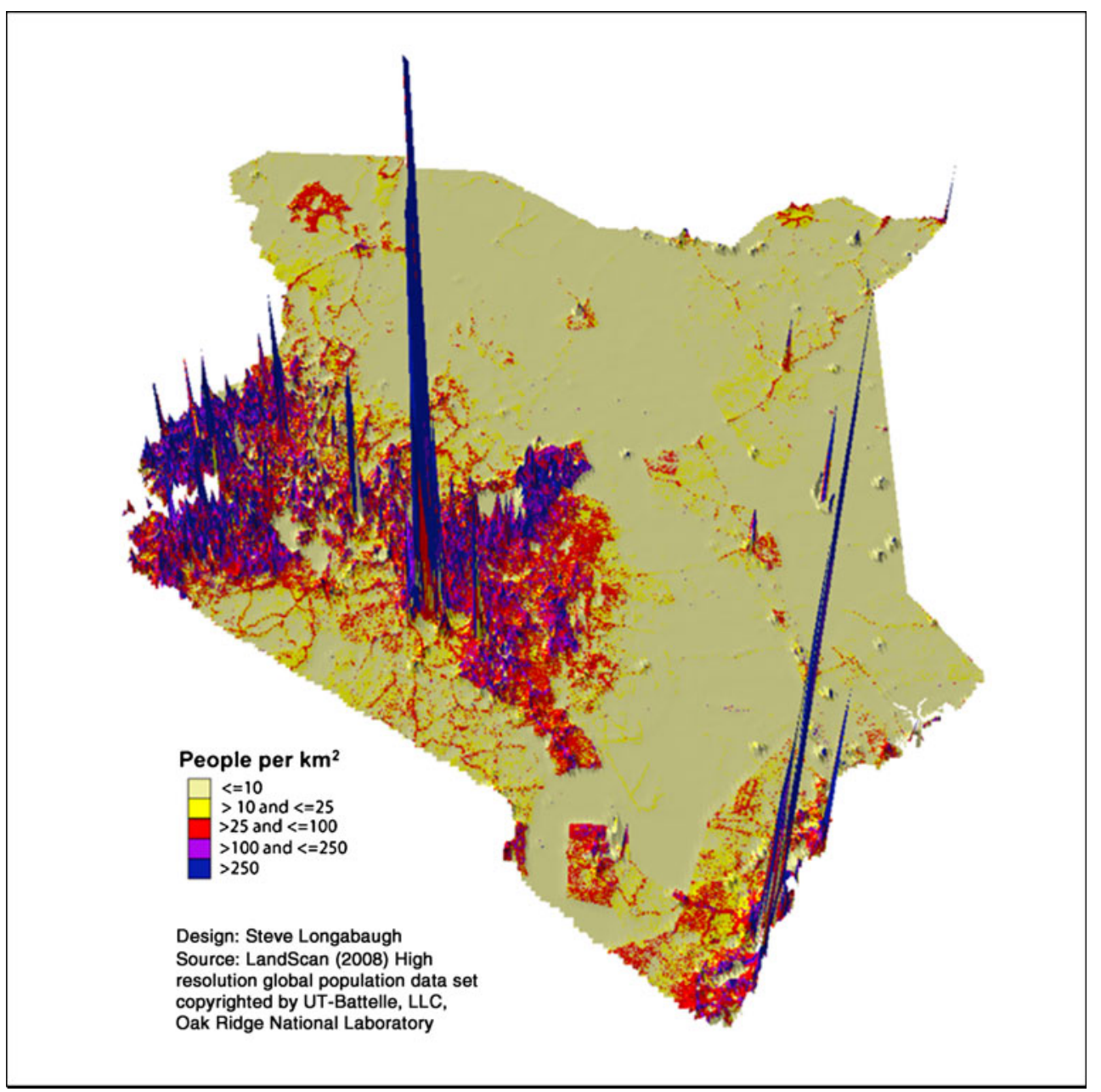

Over the past 50 years, there has been a gradual but steady decline in mean farm size as rural population growth has outstripped the growth in arable land. Table 1 shows the changes in the ratio of land cultivated to agricultural population over the past 5 decades for a number of African countries. About half of the countries in Table 1 show a

Table 1 Hectares of arable land per person in agriculture (10 year average) in selected countries

\begin{tabular}{|c|c|c|c|c|c|c|}
\hline & $1960-69$ & $1970-79$ & $1980-89$ & 1990-99 & $2000-09^{\mathrm{a}}$ & $\begin{array}{l}2000-09 \text { land-person } \\
\text { ratio as } \% \text { of } 1960-69\end{array}$ \\
\hline Ethiopia & 0.501 & 0.444 & 0.333 & 0.224 & 0.218 & $43.5 \%$ \\
\hline Zambia & 0.643 & 0.607 & 0.398 & 0.342 & 0.297 & $46.2 \%$ \\
\hline Kenya & 0.462 & 0.364 & 0.305 & 0.264 & 0.219 & $47.4 \%$ \\
\hline Uganda & 0.655 & 0.569 & 0.509 & 0.416 & 0.349 & $53.3 \%$ \\
\hline Malawi & 0.480 & 0.466 & 0.357 & 0.304 & 0.307 & $64.0 \%$ \\
\hline Zimbabwe & 0.613 & 0.550 & 0.452 & 0.420 & 0.469 & $76.5 \%$ \\
\hline Rwanda & 0.212 & 0.213 & 0.195 & 0.186 & 0.174 & $82.1 \%$ \\
\hline Mozambique & 0.356 & 0.337 & 0.320 & 0.314 & 0.294 & $82.6 \%$ \\
\hline Ghana & 0.646 & 0.559 & 0.508 & 0.492 & 0.565 & $87.5 \%$ \\
\hline Nigeria & 0.982 & 0.860 & 0.756 & 0.769 & 0.898 & $91.4 \%$ \\
\hline
\end{tabular}

Source: FAO STAT (2010)

${ }^{\text {a }}$ Data on land utilization is only available for the period 2000 to 2008 . Land-to-person ratio=(arable land and permanent crops)/(agricultural population). For the periods 1960-69 and 1970-79, agricultural population is estimated by multiplying rural population by an adjustment factor (mean agricultural population 1980-84/mean rural population 1980-84). This is because data on agricultural population was only collected from 1980 onward 
substantial decline in land-to-labor ratios in agriculture. In Kenya's case, for example, cultivated land per person in agriculture has declined from 0.462 ha in the 1960s to 0.219 ha in the $2000-08$ period. A similar picture emerges from comparisons in mean farm size within the small-scale farming sector over time. A nationally representative survey of Kenya's smallscale farm sector in 1977 carried out by the Central Bureau of Statistics reports mean farm size ranging across provinces from 2.10 to 3.48 ha. By contrast, mean farm size in Egerton University's nationwide surveys from 1997 to 2010 show mean farm size to be 1.86 ha per farm; these longitudinal surveys show a decline in farm size even within that 13-year period.

But why should smallholder farms be shrinking over time? Coming to grips with this question requires understanding why much of Africa's rural population tends to be concentrated tightly in particular areas while vast areas potentially suitable for agriculture remain largely unutilized. Figure 2 shows that roughly $40 \%$ of Kenya's rural population resides on $5 \%$ of its arable land. On the other end of the continuum, $3 \%$ of the population controls $20 \%$ of the land.

Research suggests two answers to the apparent land "scarcity amidst abundance" paradox. First, potentially arable land can remain underutilized because it has yet to receive the requisite public investment in physical infrastructure (e.g., roads, electrification, irrigation), water, schools, health facilities and other services required to raise the economic value of land and thereby attract migration and settlement in these areas (Jayne et al. 2009). Several governments in the region have shown a willingness to make such land available for large-scale commercial investment but not for smallholder-led agricultural development. This explains to some extent the large-scale acquisitions of farmland in Africa by foreign countries that has come to be popularly known as "land grabs". Second, and potentially even more important in countries with a colonial settler history such as Kenya, Malawi, Zimbabwe, and Zambia, has been the historical and post-independence continuation of colonial tenure systems separating "customary lands" from "state lands" (Deininger and Binswanger 1995; Woodhouse 2003). Many areas under customary tenure are facing emerging land constraints borne of steady rural population growth since independence. By contrast, much of Africa's unutilized arable land is under state authority, which is not readily accessible for settlement by smallholder populations under prevailing land allocation institutions. Post-independence governments have often allocated land to non-farming elites in exchange for political support, contributing to land underutilization while nearby customary farming areas exhibit signs of land pressures and degradation (Kanyinga 1998; Mbaria 2001; Stambuli 2002; Namwaya 2004). It is perhaps not surprising then that median farm sizes are quite small and declining for the vast majority of the farming population, as shown in Table 1, while large tracts of land in other parts of the country remain unutilized.

The relationship between landholding size and household income in primarily agrarian rural settings is well established. Figure 3 shows the relationship between farm size per adult equivalent and income. Increases in farm size below 0.5 ha per capita (roughly 2.5 ha farms when adjusting for mean family size) are associated with large increases in household income. Beyond about 0.5 ha per capita, the relationship flattens out. Because most smallholder farms, and especially the poorest ones, are well below 2.5 ha in size, it is likely that measures to promote access to land may reap very high payoffs in terms of rural poverty reduction.

What do such land-income relationships mean for feasible smallholder-led development pathways? The structural transformation processes in Asia, as documented by pioneering development economists such as Johnston and Kilby (1975) and Mellor (1976), show that a smallholderled agricultural strategy was necessary to rapidly reduce rural poverty and induce demographic changes associated with structural transformation. An inclusive smallholder-led

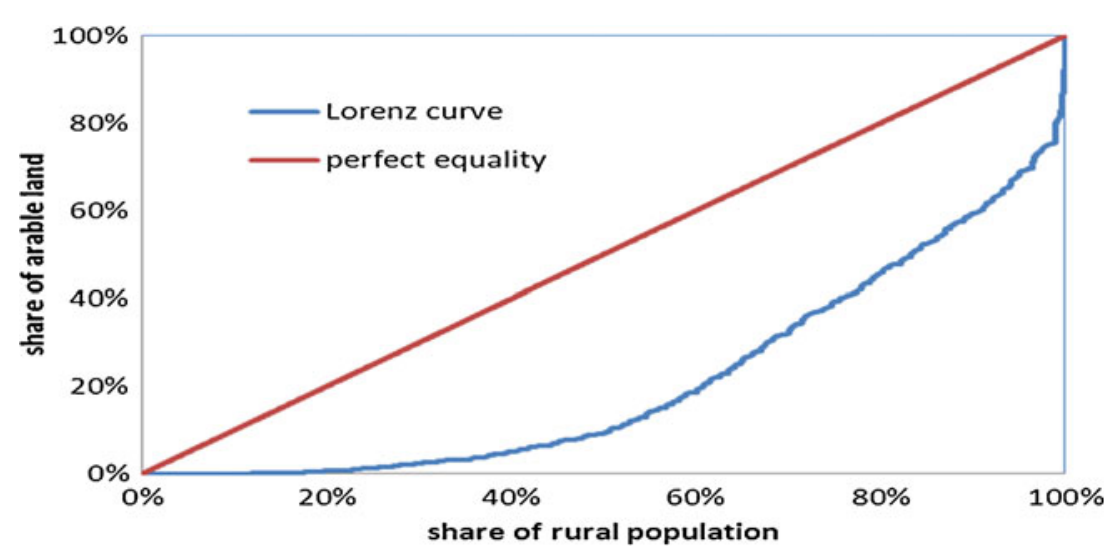

Fig 2 Lorenz curve showing the percentage of arable land by percentage of rural population in Kenya, 2009. Gini coefficient: 0.51. Source: population data from 2009 Kenya National Bureau of Statistics Census; arable land from Columbia University Global Rural-urban Mapping

Project (GRUMP). A Lorenz curve shows the degree of inequality that exists in the distributions of two variables, and is often used to illustrate the extent that income or wealth is distributed unequally in a particular society 

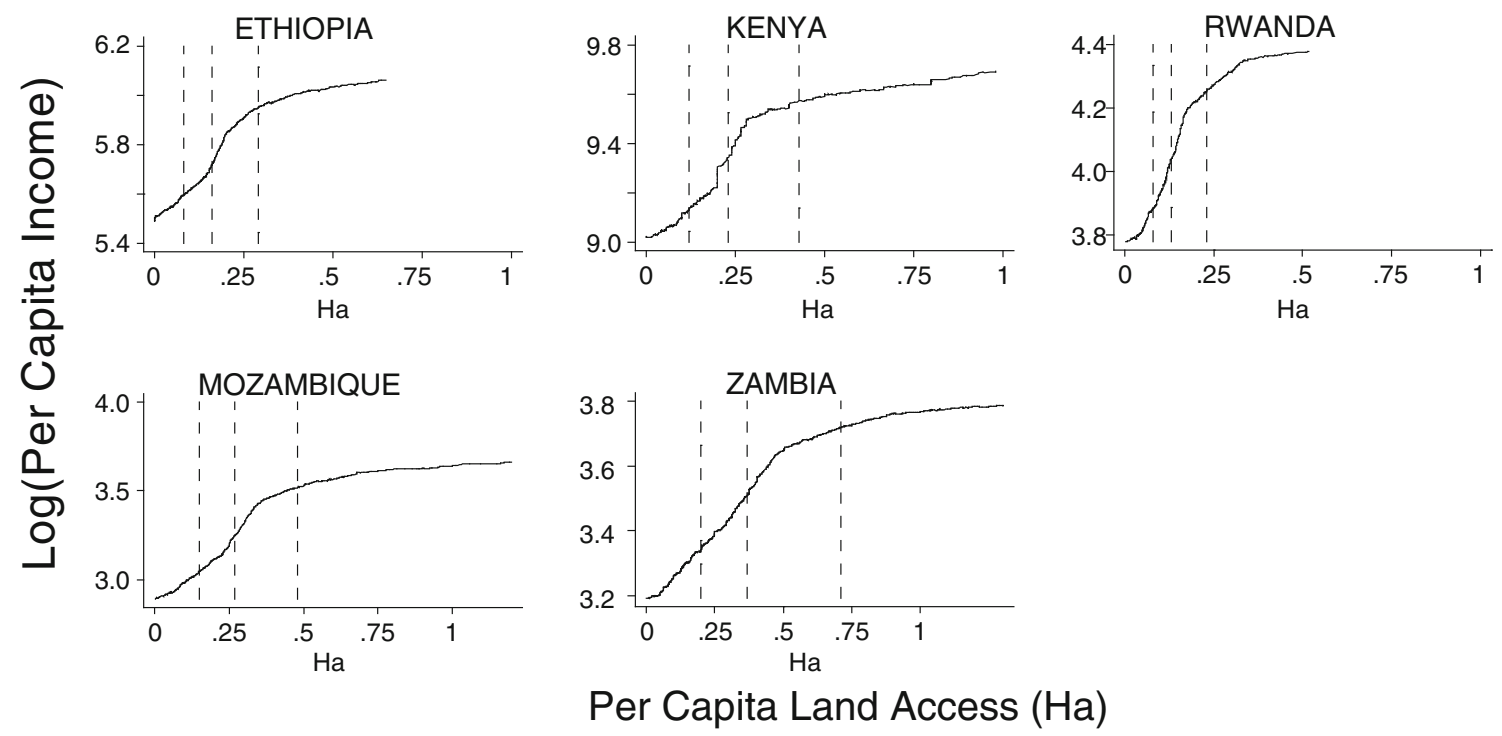

Note: The vertical lines are drawn at 25th, 50th, and 75th percentiles of per capita land owned for each country. The top 5 percent of observations are excluded from the graphs because lines are sensitive to a few extreme cases .

Fig 3 Bivariate cross-country relationships between landholding size and household incomes per capita. Source: Jayne et al. 2009

strategy is likely to provide the greatest potential to achieve agricultural growth with broad-based reductions in rural poverty in most of sub-Saharan Africa as well. However, it is not at all clear how such a smallholder-led agricultural strategy must be adapted to address the limitations of very small and declining farm sizes in densely populated areas that are dependent on rain-fed production systems with only one growing season per year. ${ }^{1}$

To our knowledge, there has been very little recognition of the potential challenges associated with increasingly densely populated and land-constrained areas of rural Africa. Nor has there been sufficient discussion of how institutions and policies relating to land access would need to be modified to achieve inclusive smallholder-led agricultural growth leading to rural poverty reduction.

This study is motivated by the need to understand the nature and magnitude of emerging land constraints in African

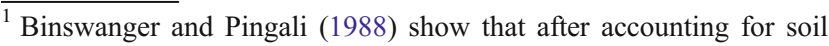
and climate conditions as well as potential technological options, it is possible to compute standardized agroclimatic population densities for various countries measuring the number of people per million kilocalories of production potential. They report that when countries are ranked conventionally by population per square kilometer of agricultural land, Bangladesh comes first, India comes seventh, Kenya falls somewhere in the middle, and Niger is near the bottom. When ranked by agro-climatic population density, the rankings change dramatically: Niger and Kenya are more densely populated than Bangladesh is today, and India ranks only twenty-ninth on the list.
}

agriculture, the possible impacts of status-quo policies and institutions on food security and poverty, and the potential for institutional reforms to address these challenges. Kenya is a useful case study to examine these issues, given that it is one of the more densely populated countries in the region and may therefore provide an advance picture of the dynamics that other countries in the region are likely to be experiencing in the not too distant future.

\section{Conceptual framework and hypotheses}

There are several alternative ways to cast the issue of emerging land constraints within smallholder farming areas in Africa. One way is to ask how various rates of change in rural population density are affecting the evolution of farming systems, including technical and institutional responses to increased land constraints. Of course, the ways in which increasing population density affects farming systems and smallholder input demand and output supply behavior is primarily through factor and food prices. Hayami and Ruttan's (1971) theory of induced innovation has repeatedly shown that changes in person-land ratios cause farmers to adapt their farming system in ways that can be predicted. Other factors constant, rising labor-land ratios cause land values to rise compared to agricultural labor, and indirectly induce farmers to adopt new technologies that are land-saving. Other seminal works examining the ways that land-abundant agricultural systems evolve in response to growing population density 
include Boserup (1965), Binswanger and Ruttan (1978), and Pingali and Binswanger (1988). Binswanger and McIntire (1987) argued that increases in rural population density should induce a number of changes on tropical agricultural farming systems, including declining labor productivity, decreased fallows, increased landlessness, the development of land, labor and informal financial markets, and declining livestock tenancy. As rural communities become more heavily populated, farmers transition from shifting cultivation to annual cropping of the same plots. Fallows are reduced and more labor time is devoted to each unit of land, e.g., weeding labor per hectare rises (Table 2). Farmers further search for land-saving technologies such as fertilizer and hybrid seed to raise the returns to the scarce factor of production (land). Given this kind of innovation, Binswanger and McIntire argue that through input intensification farmers can raise land productivity and maintain or raise labor productivity growth even in the context of rising labor/land factor proportions. This literature has largely explained how many agricultural systems in Africa over the past 100 years have transitioned from one end of the continuum in Table 2, shifting cultivation, to the other side of the continuum, intensive annual or multiple cropping with less and less land being held in fallow to restore soil productivity.

However, this literature for the most part has not considered what lies beyond the end of the continuum of annual and multiple cropping in the context of emerging land constraints and ever smaller farm sizes in increasingly densely populated rural areas. In the past two decades since these seminal articles were written, there is evidence of increased population pressures within many smallholder farming areas. Can land intensification be increased on ever smaller farms without incurring diminishing returns and scale-diseconomies? This leads to another set of research questions about appropriate and feasible smallholder-led agricultural strategies in the context of land constrained farming systems and limited off-farm employment opportunities to absorb redundant labor in densely populated rural areas. Important policy issues therefore revolve around whether most farms are becoming, or have already become, "too small" to generate meaningful production surpluses and participate in broad-based inclusive agricultural growth processes given existing on-shelf production technologies. This is the primary question that this study addresses. While we will not be able to fully address this question, our aim is to examine how densely populated farming areas are evolving compared to less densely populated areas, and to assess whether farm households in the densely populated areas are able to generate sufficient farm surpluses and incomes through agriculture (given existing technologies) to reduce rural poverty. We then examine the implications for policies and institutions governing land allocation in Kenya.

Our hypothesis is that farm households in the relatively densely populated areas will exhibit evidence of declining farm size, constraints on farm intensification, and lower surplus production, incomes and asset wealth, especially per labor unit, than households in less land-constrained areas. We also anticipate that densely populated rural areas may show a greater outflow of labor off the farm, and disproportionally contribute to rapid urbanization.

\section{Data}

Rural population data is available from the past five national censuses carried out in 1969, 1979, 1989, 1999, and 2009. More disaggregated data on rural population, land under agriculture, and unutilized land suitable for agriculture within

Table 2 Farming operations in different farming systems

\begin{tabular}{|c|c|c|c|c|c|}
\hline & $\begin{array}{l}\text { Forest fallow } \\
\text { system }\end{array}$ & $\begin{array}{l}\text { Bush fallow } \\
\text { system }\end{array}$ & $\begin{array}{l}\text { Short-fallow } \\
\text { system }\end{array}$ & $\begin{array}{l}\text { Annual } \\
\text { cultivation } \\
\text { system }\end{array}$ & $\begin{array}{l}\text { Multiple } \\
\text { cropping } \\
\text { system }\end{array}$ \\
\hline $\begin{array}{l}\text { Labor-land ratios } \\
\text { (reflecting pop. } \\
\text { density) }\end{array}$ & Low & & & $\longrightarrow$ & high \\
\hline Land preparation & $\begin{array}{c}\text { no land } \\
\text { preparation }\end{array}$ & $\begin{array}{l}\text { use of hoe to } \\
\text { loosen soil }\end{array}$ & plow & $\begin{array}{l}\text { animal-drawn } \\
\text { plow }\end{array}$ & $\begin{array}{c}\text { animal drawn } \\
\text { plow and } \\
\text { tractor }\end{array}$ \\
\hline Fertilization & ash & ash & $\begin{array}{c}\text { manure, green } \\
\text { manure }\end{array}$ & $\begin{array}{c}\text { green manure, } \\
\text { inorganic } \\
\text { fertilizer }\end{array}$ & $\begin{array}{l}\text { inorganic } \\
\text { fertilizer }\end{array}$ \\
\hline Weeding & minimal & $\begin{array}{l}\text { required as } \\
\text { length of fallow } \\
\text { decreases }\end{array}$ & $\begin{array}{l}\text { intensive } \\
\text { weeding } \\
\text { required }\end{array}$ & $\begin{array}{l}\text { intensive } \\
\text { weeding } \\
\text { required }\end{array}$ & $\begin{array}{l}\text { intensive } \\
\text { weeding } \\
\text { required }\end{array}$ \\
\hline
\end{tabular}

Condensed and adapted from Binswanger and Pingali (1988) 
$10 \mathrm{~km}^{2}$ pixels are used from the Global Rural-urban Mapping Project (GRUMP). ${ }^{2}$ We also draw from the nationwide Egerton University/Tegemeo Institute Rural Household Survey, a panel dataset tracking roughly 1,300 small-scale farm households in 5 survey waves over the 13-year period from 1997 to 2010. The sampling frame for the panel was prepared in consultation with the Kenya National Bureau of Statistics (KNBS) in 1997. Twenty four (24) districts were purposively chosen to represent the broad range of agroecological zones (AEZs) and agricultural production systems in Kenya. ${ }^{3}$ Next, all non-urban divisions in the selected districts were assigned to one or more AEZs based on agronomic information from secondary data. Third, proportional to population across AEZs, divisions were selected from each AEZ. Fourth, within each division, villages and households in that order were randomly selected. In the initial survey in 1997, a total of 1,500 households were surveyed in 109 villages in 24 districts within eight agriculturally-oriented provinces of the country. Subsequent surveys were conducted in June of 2000, 2004, 2007 and 2010. Over these 5 panel surveys, 1,243 household were able to be consistently located and surveyed. For this analysis, farms over 20 ha (50 acres) were dropped to retain the study's focus on smallholder agriculture. Households in the coastal areas were also excluded because farming is found to account for a relatively small share of household incomes. This leaves a balanced panel of 1,146 households surveyed consistently in each of the 5 years.

The surveys collect information on demographic changes, movements of family members in and out of the household since the prior survey, landholding size, land transactions and renting, farming practices, the production and marketing of farm products, and off-farm income-earning activities. ${ }^{4}$

We superimposed the longitude-latitude coordinates of the 109 villages in the Tegemeo survey on the $10 \mathrm{~km}^{2}$ pixel population density estimates from the Global Urban-rural Mapping Project database for 2009 , to obtain population density estimates for each village. Population densities in the sample ranged from 44 persons per $\mathrm{km}^{2}$ in the case of Laikipia West to 965 persons per $\mathrm{km}^{2}$ in Vihiga District. We then stratified these 109 villages into five population density groups, or quintiles. Population densities range from 30 to 147 persons per $\mathrm{km}^{2}$ in the lowest quintile, 148 to 313 in the second quintile, 315 to 470 in the third quintile, 475 to 655 in the fourth quintile, and 659 to 1,135 persons per $\mathrm{km}^{2}$ in the highest quintile. We then examine how the five groups are

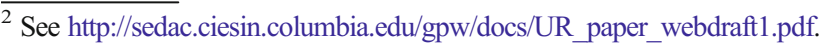
${ }^{3}$ Since the study was conducted, the administrative units under the New Constitution have been changed from Districts to Counties, although the physical boundaries are often different.

${ }^{4}$ Each of these survey instruments, which contain the details of the types of information collected and used in this study, can be viewed and downloaded at http://www.aec.msu.edu/fs2/kenya/index.htm.
}

evolving differently over the 1997-2010 period in terms of three main features:

i. Demographic trends: changes in net migration of adults out of the area.

ii. Farming patterns: changes in farm size, land values, rental rates, land-to-labor ratios, input intensity per unit of land cultivated and cropping patterns. The 2007 survey also contains a module exploring household members' inheritance of land and the amount of land controlled by their parents.

iii. Farm production, assets and household incomes: changes in incomes from crops, animal production, and nonfarm income as well as household asset holding.

\section{Econometric models}

To study the effect of population density on specific behaviors or outcomes for household $i$ in time $t\left(\mathrm{y}_{i t}\right)$, we estimate a series of reduced form unobserved panel effects models for the following dependent variables: farm size and area under crop cultivation; intensity of cash inputs use as a measure of the level of agricultural land intensification; and indicators of household welfare such as incomes per adult equivalent and asset holding. The models take the form:

$$
\begin{aligned}
y_{i t} & =\alpha_{i}+X_{i t} \beta+W_{i t} \eta+R_{i} \lambda+D_{t} \kappa+\mu_{i t}, \\
i & =1,2, \ldots, N, t=1,2, \ldots, T
\end{aligned}
$$

where $X_{i t}$ is a vector of household-level time-varying variables; $W_{i t}$ is a vector of village-level time-varying variables; $R_{i}$ is a vector of village-level time-constant variables; and $D_{t}$ is a vector of survey year dummies. The letter $\alpha_{i}$ represents the unobserved, time-constant heterogeneity that affects $y_{i t}$ while $\mu_{i t}$ is the error term. ${ }^{5}$ The vector $X_{i t}$ includes variables such as distances to infrastructural facilities and services; $W_{i t}$ includes village-level population density (the main variable of interest), input prices (agricultural wage rates, land rental rates, and fertilizer prices), rainfall quantity (6-year moving average of annual rainfall prior to each survey) and rainfall variability (6year moving average of the percentage of 20-day periods during the main growing season in which rainfall was less than $40 \mathrm{~mm}$ ) indicators. The $R_{i}$ vector includes land quality (potential kilocalories from $10 \mathrm{~km}^{2}$ pixel land area) and agroecological dummies capturing other village-level timeconstant characteristics. We also test for potential non-linear

\footnotetext{
${ }^{5}$ Omitted variables are the main source of unobserved heterogeneity, and they may fall into two categories: those that do not vary much across time (e.g., distance from the farm to the district town), which are easier to control for with panel analysis techniques as used here, and those that are time-varying (e.g., random shocks affecting households). For details on unobserved heterogeneity and methods for addressing it, see Wooldridge (2010).
} 
relationships between the dependent variables and population density by including squared, and if necessary, cubed density terms.

If the model outlined in (1) represents the true data generating mechanism, then the existence of correlation between independent variables and unobserved heterogeneity, if uncontrolled for, would result in inconsistent estimates in applied research. With panel data, there are two popular methods for estimating this model, fixed and random effects, each with their own benefits and costs. The main drawback of the random effects estimator is that it relies on the fairly strong, and in our case infeasible, assumption that the unobserved heterogeneity is uncorrelated with any of the observed independent variables. The fixed effects estimator relaxes this assumption, but at the cost of not being able to include any time-constant covariates, such as the locations where sampled households are situated. To overcome these shortcomings of both fixed and random effects estimators, Mundlak (1978) and Chamberlain (1984) propose a framework known as the correlated random effects estimator (CRE) or the Mundlak-Chamberlain device. In this approach, rather than assuming the unobserved and observed explanatory variables are uncorrelated, $\alpha_{i}$ is modeled and the correlation is assumed to take the form:

$\alpha_{i}=\delta+\bar{C}_{i} \lambda+\varsigma_{i}, \varsigma_{i} \mid C_{i} \sim N\left(0, \sigma_{\varsigma}^{2}\right)$

where $\bar{C}_{i}$ represents the time-averaged value of all time varying variables $\left(X_{i t}\right.$ and $\left.W_{i t}\right)$ over the various panel periods. The main benefits of the CRE estimator are that (1) it controls for unobserved time-constant heterogeneity, and (2) because the assumption of correlation between the covariates and unobserved heterogeneity is modeled, the random effects estimator is applied, which allows also the measurement of the effects of time-invariant independent variables (see Wooldridge 2010 for details).

While Equations (1) and (2) are linear in parameters, and thus easily estimated by any single equations estimator, the population density variable is potentially endogenous in equation (Eq. 1). There is a possibility that some unobservables that influence agricultural production and household welfare are likely to influence population growth. When confronted by endogeneity, two methods are available to circumvent the problem. First is the usual instrumental variable (2SLS) method and the second is the control function (CF) approach (Wooldridge 2010). While the two methods yield the same results, the $\mathrm{CF}$ approach leads to a straightforward exogeneity test of the potentially endogenous variable. We therefore apply the CF approach in the paper. The CF approach involves twostep estimation procedure. In the first step, we estimate

$d=z \pi+v, v \mid z \sim N\left(0, \sigma_{v}^{2}\right)$

where $d$ is the population density in village $g$ at survey period $t, z$ is a vector of exogenous variables (which includes unity as its first element), $\pi$ 's are the coefficients to be estimated; and $v$ is a random error term. The vector $z$ is supposed to contain at least one element that is not in equation (Eq. 1) for identification purposes. In our case the vector $z$ includes the population estimates from the 1969 and 1979 censuses for each village; factors measuring access to markets and infrastructure; and rainfall quantity and variability variables as well as small agro-ecological dummies to capture general agro-ecological potential in the villages where the households are found.

In the second step we estimate specifications (1) but this time plugging in the residual, $\widehat{v}$, from (3) using the CRE approach. As Wooldridge (2010) shows, plugging $\widehat{v}$ into equations (Eq. 1) breaks the endogeneity link between the potentially endogenous variable and the error term in equation (Eq. 1). The time-varying explanatory variables in both steps are lagged by one survey period for two reasons. First, while some explanatory variables may affect asset stocks contemporaneously, most of the variables are expected to influence asset stocks after a lag. For example, changes in the distance to infrastructural facilities and services often do not affect agricultural production and household asset accumulation immediately; these effects tend to appear with a lag. The second reason is to circumvent any other potential endogeneity problem arising from omitted variable problems. It is important to note that since the estimation of equation (Eq. 1) involves generated regressor $(\widehat{v})$, standard errors generated by most econometric software for the coefficients are bound to invalid since they ignore the sampling variation in the estimation of $\pi$ in the first step. Disregarding the sampling error in the generated regressors $(\widehat{v})$ is likely to underestimate the computed standard errors in equation (Eq. 1). Consequently, we use the bootstrap approach with 500 replications to get a valid estimate of the standard errors. Inferences from equation (Eq. 1) are made fully robust to arbitrary heteroskedasticity and serial correlation (Wooldridge 2010).

\section{Descriptive results}

Consistent with demographic studies showing fairly rapid ruralto-urban migration in most of sub-Saharan Africa, including Kenya (World Bank 2008), our panel survey data show a fairly consistent net outflow of adults out of the area over the 19972010 period. However, after disaggregating households into quintiles according to the population density of their village, we find a higher net outflow of labor in the relatively densely populated villages. ${ }^{6}$ Over the entire period, the net outflow of labor from households in the most densely populated quintile

\footnotetext{
${ }^{6}$ The survey did not ask respondents to indicate the whereabouts of adults listed in prior surveys but not resident in the current survey, but we were able to identify and exclude cases based on marriage and death because the survey asked explicitly about these events in other modules of the surveys.
} 
was 2.8 times higher than villages in the least densely populated quintile. While causality cannot be ascribed, these findings are consistent with our expectations. Densely populated rural areas are more likely to experience surplus labor and underemployment, especially in the context of land pressures and limited means to further subdivide small farms. By contrast, in sparsely populated areas, the demands for labor in agriculture are likely to be greater, hence slowing the net outflow of rural labor.

Table 3 presents information on farm size and farming practices by village population density quintiles over the four survey years. Landholding sizes per adult equivalent in the $20 \%$ most densely populated villages $(0.31$ ha over the four survey years) are roughly one third of those in the low density quintile $(0.92 \mathrm{ha})$. The areas under cultivation have consistently declined for all five population density categories over the 10 -year period by about $23 \%$. The areas cultivated in the highest density (HD) quintile ( 0.89 ha) are about half of those in the lowest density (LD) quintile (1.80 ha). These differences between the top and bottom quintiles of farm size and area under cultivation are significant at the $95 \%$ confidence level. The proportion of farmland under fallow has also declined slightly over time for all population density quintiles. Family labor per hectare cultivated has generally increased over the 13-year period, and is significantly higher in the HD quintile than all other density quintiles. All of these indicators

Table 3 Farming practices and factor intensities, by population density quintile (all values in nominal terms)

\begin{tabular}{|c|c|c|c|c|c|c|c|}
\hline & \multirow[t]{2}{*}{ Pop. density quintile } & \multicolumn{4}{|c|}{ Survey year } & \multicolumn{2}{|c|}{ Four survey panel } \\
\hline & & 2000 & 2004 & 2007 & 2010 & average & $95 \% \mathrm{CI}$ \\
\hline \multirow{5}{*}{$\begin{array}{l}\text { Landholding per adult } \\
\text { equivalent (hectares) }\end{array}$} & 5 [highest] & 0.28 & 0.29 & 0.35 & 0.30 & 0.31 & {$\left[\begin{array}{lll}0.27 & 0.34\end{array}\right]$} \\
\hline & 4 & 0.34 & 0.37 & 0.47 & 0.36 & 0.38 & {$\left[\begin{array}{ll}0.36 & 0.41\end{array}\right]$} \\
\hline & 3 & 0.45 & 0.50 & 0.49 & 0.45 & 0.47 & {$\left[\begin{array}{ll}0.44 & 0.51\end{array}\right]$} \\
\hline & 2 & 0.55 & 0.61 & 0.56 & 0.63 & 0.59 & {$\left[\begin{array}{ll}0.54 & 0.65\end{array}\right]$} \\
\hline & 1 [lowest] & 0.83 & 0.96 & 0.93 & 0.95 & 0.92 & {$\left[\begin{array}{ll}0.85 & 0.99\end{array}\right]$} \\
\hline \multirow{5}{*}{$\begin{array}{l}\text { Area cultivated in the main } \\
\text { season (hectares) }\end{array}$} & 5 [highest] & 0.99 & 0.94 & 0.85 & 0.79 & 0.89 & {$\left[\begin{array}{ll}0.85 & 0.94\end{array}\right]$} \\
\hline & 4 & 1.18 & 1.26 & 1.22 & 1.03 & 1.17 & {$\left[\begin{array}{ll}1.10 & 1.24\end{array}\right]$} \\
\hline & 3 & 1.54 & 1.36 & 1.16 & 0.99 & 1.27 & {$\left[\begin{array}{ll}1.20 & 1.35\end{array}\right]$} \\
\hline & 2 & 1.73 & 1.79 & 1.54 & 1.30 & 1.58 & {$\left[\begin{array}{ll}1.48 & 1.67\end{array}\right]$} \\
\hline & 1 [lowest] & 1.98 & 1.87 & 1.74 & 1.59 & 1.80 & {$\left[\begin{array}{ll}1.68 & 1.91\end{array}\right]$} \\
\hline \multirow{5}{*}{$\begin{array}{l}\text { Labor (number of adult members) } \\
\text { per hectare cultivated }\end{array}$} & 5 [highest] & 6.04 & 7.15 & 5.94 & 6.43 & 6.39 & {$\left[\begin{array}{lll}5.84 & 6.94\end{array}\right]$} \\
\hline & 4 & 4.54 & 4.12 & 4.19 & 4.71 & 4.39 & [4.12 4.67] \\
\hline & 3 & 5.14 & 5.18 & 4.81 & 4.67 & 4.96 & {$\left[\begin{array}{lll}4.47 & 5.46]\end{array}\right]$} \\
\hline & 2 & 3.10 & 3.19 & 3.65 & 3.57 & 4.49 & {$\left[\begin{array}{ll}2.33 & 6.65\end{array}\right]$} \\
\hline & 1 [lowest] & 3.06 & 3.11 & 3.34 & 3.15 & 3.16 & {$\left[\begin{array}{lll}2.94 & 3.39\end{array}\right]$} \\
\hline \multirow{5}{*}{$\begin{array}{l}\text { Cost of purchased inputs per } \\
\text { hectare ('000 KSh) }\end{array}$} & 5 [highest] & 13.62 & 15.45 & 14.60 & 19.36 & 15.73 & {$\left[\begin{array}{lll}14.94 & 16.51\end{array}\right]$} \\
\hline & 4 & 17.13 & 21.26 & 18.98 & 26.63 & 21.07 & {$\left[\begin{array}{lll}19.88 & 22.27\end{array}\right]$} \\
\hline & 3 & 12.16 & 15.74 & 13.76 & 21.29 & 15.57 & {$\left[\begin{array}{lll}14.07 & 17.07\end{array}\right]$} \\
\hline & 2 & 5.71 & 12.34 & 13.57 & 17.60 & 12.65 & {$\left[\begin{array}{ll}11.58 & 13.71\end{array}\right]$} \\
\hline & 1 [lowest] & 8.10 & 8.72 & 9.63 & 13.17 & 9.87 & {$\left[\begin{array}{lll}8.60 & 11.13\end{array}\right]$} \\
\hline \multirow[t]{5}{*}{ Land values/ha ('000 KSh) } & 5 [highest] & - & - & - & 703.02 & 703.02 & {$\left[\begin{array}{lll}541.27 & 864.78\end{array}\right]$} \\
\hline & 4 & - & - & - & 633.03 & 633.03 & {$[359.66906 .40$} \\
\hline & 3 & - & - & - & 723.67 & 723.67 & {$[479.64967 .70]$} \\
\hline & 2 & - & - & - & 626.00 & 626.00 & {$\left[\begin{array}{lll}276.30 & 975.70\end{array}\right]$} \\
\hline & 1 [lowest] & - & - & - & 271.82 & 271.82 & {$\left[\begin{array}{lll}103.76 & 439.87\end{array}\right.$} \\
\hline \multirow{5}{*}{$\begin{array}{l}\text { Hired agricultural wage labor rate } \\
\text { (KSh. per day) }\end{array}$} & 5 [highest] & 59.24 & 68.95 & 72.81 & 102.52 & 75.68 & {$\left[\begin{array}{lll}73.85 & 77.51\end{array}\right]$} \\
\hline & 4 & 71.20 & 93.49 & 95.53 & 137.74 & 100.07 & {$\left[\begin{array}{ll}97.57 & 102.56\end{array}\right]$} \\
\hline & 3 & 67.67 & 76.52 & 83.68 & 117.72 & 85.39 & {$\left[\begin{array}{lll}83.37 & 87.42\end{array}\right]$} \\
\hline & 2 & 69.38 & 92.56 & 96.07 & 134.21 & 99.97 & {$\left[\begin{array}{ll}97.19 & 102.76\end{array}\right]$} \\
\hline & 1 [lowest] & 83.12 & 97.40 & 105.00 & 124.93 & 102.14 & [99.99 104.29 ] \\
\hline
\end{tabular}

Source: Tegemeo institute rural household surveys

Notes: Population density quintiles are defined by ranking all households in the surveys by village-level population density and dividing them into five equal groups 
point to land being an increasingly constraining factor of production in smallholder agriculture in the high-density areas in Kenya.

Land constraints may also explain why the HD areas tend to be devoting a greater share of their cropped area to highervalued crops and less to maize, a relatively low-value crop (data not shown to conserve space). Villages in the HD quintile put less than $3 \%$ of their land to monocropped maize, compared to $6 \%$ in the lowest density quintile. Maize intercrops account for $39 \%$ of cropped areas in the highest density areas compared to $42 \%$ in the lowest density areas. However, this difference is not statistically significant. By contrast, the $\mathrm{HD}$ areas devote a significantly greater share of their land to industrial cash crops such as tea, coffee, and sugarcane compared to the bottom two density quintiles. Similarly, fresh fruits and vegetables account for $26 \%$ of cropped area in the $\mathrm{HD}$ areas, compared to $13 \%$ in the $20 \% \mathrm{LD}$ villages. Also, the percentage of households practicing zero-grazing increases with population density from a low of $4 \%$ in the first population density quintile, reaching a high of $56 \%$ in the 4 th quintile and declining to $31 \%$ in the HD quintile. Similarly, Table 3 shows that the intensity of purchased inputs (mainly fertilizer, improved seed, and hired labor) per unit of land is an increasing function of population density up to the 4th density quintile, but then declines significantly from the fourth to the highest density quintile. The greater focus on high-value crops and more intensive land-saving dairy production in the densely populated regions maximizes revenue per scarce unit of land owned. This is a result that will be explored further in the econometrics section of the paper.

Land values, collected in 2010 were more than twice as high in the three highest population density quintiles than in the LD quintile. Conversely, agricultural wage rates in the LD villages were $30 \%$ higher than in the HD villages (Table 3 ). The overall picture from Table 3 is that farming practices in the areas of high population density are distinctly more landintensive and are focused more on higher-value crops than in the low density areas.

Not shown in Table 3, but also of importance is how population density is related to the amount of land inherited from the previous generation. Respondents in the 2007 survey were asked how much land was owned by the father of the household head. The previous generation had considerably larger farms (3 times larger) than those of the current survey respondents themselves. The mean size of parents' farms varied from 7.80 ha in the LD areas to 4.41 ha in the HD areas. Survey respondents were also asked about the amount of land inherited by the household head from his father. This ranged from 1.49 ha in the LD quintile to 0.89 ha in the HD quintile. The mean amount of land inherited was roughly onefifth of the total landholding size of the father. This might be explained by the fact that fathers in patriarchal Kenya tend to subdivide their land among sons. An important policy question might be how the current generation of adults in the high population density areas with 1.30 ha of land or less are going to subdivide their land among their children when they reach their old age (the average age of household heads was 48 years in 2010) and whether farming can provide a viable livelihood for those remaining on the land. We speculate that, because farm sizes in the high density areas are already quite tiny and cannot be meaningfully subdivided much further, an increasingly smaller fraction of people born on farms in Kenya will be able to remain there. This may point to even higher rates of rural-to-urban migration in the future, or at least from agriculture to non-agriculture.

Table 4 presents trends in farm production, income, and asset wealth over the panel period by village population density quintiles. The value of net crop income (gross crop income minus input costs per hectare), a measure of partial land productivity, increases with population density up to the fourth density quintile and declines thereafter. As shown by results in Table 3, high population density areas are cultivating their scarce land more intensively by applying more labor and cash inputs per hectare cultivated, at least up to a certain threshold corresponding to the fourth highest population density quintile, which ranged from 531 to 678 persons per $\mathrm{km}^{2}$. Similarly, the value of net farm income (from crops and animal products) per hectare also is an increasing function of population density up to a certain level corresponding to the fourth-highest quintile. By contrast, the value of farm income per family labor unit appears to be higher among the villages in the middle population density quintiles. This measure of partial labor productivity is perhaps the more meaningful of the two productivity measures because it more accurately reflects the implicit return to an individual. Table 4 also shows that off-farm income per adult equivalent is slightly higher for households in the low density areas, possibly reflecting a lower supply of labor in these areas (note also from Table 3 that agricultural wage rates were also higher in the low density areas than in high density areas).

Possibly the most important indicator discussed in this section is the value of asset wealth per adult equivalent. The list of productive assets consistently collected and valued in each of the four surveys includes ploughs, tractors and draft animal equipment, carts, trailers, cars, trucks, spray pumps, irrigation equipment, water tanks, stores, wheelbarrows, combine harvesters, cows, bulls, donkeys, and smaller animals. Recent studies in the poverty literature (e.g., Carter and Barrett 2006; Krishna et al. 2004) argue that the value of assets more accurately measures wealth than income or consumption, as it is less susceptible to random shocks, and is likely to be a more stable indicator of household welfare. This is especially true in regions where rain-fed agriculture is a major source of annual income and where households rely greatly on their physical assets for their livelihoods. For these reasons, we consider asset holdings 
Table 4 Household income and wealth trends, by population density quintile ('000 KSh nominal)

\begin{tabular}{|c|c|c|c|c|c|c|c|c|}
\hline & \multirow[t]{2}{*}{ Pop den quintile } & \multicolumn{5}{|c|}{ Survey year } & \multicolumn{2}{|c|}{ Five survey panel } \\
\hline & & 1997 & 2000 & 2004 & 2007 & 2010 & average & $95 \% \mathrm{CI}$ \\
\hline \multirow[t]{5}{*}{ Net crop income per hectare } & 5 [highest] & 27.17 & 55.47 & 48.67 & 57.67 & 64.69 & 50.83 & [47.06 54.60] \\
\hline & 4 & 27.30 & 49.06 & 50.19 & 58.40 & 120.84 & 61.36 & {$\left[\begin{array}{lll}56.58 & 66.14\end{array}\right]$} \\
\hline & 3 & 22.35 & 33.71 & 37.88 & 45.98 & 75.44 & 42.35 & {$\left[\begin{array}{ll}39.15 & 45.54\end{array}\right]$} \\
\hline & 2 & 16.41 & 20.47 & 30.77 & 42.79 & 53.77 & 33.58 & {$\left[\begin{array}{lll}30.43 & 36.73\end{array}\right]$} \\
\hline & 1 [lowest] & 17.40 & 21.74 & 20.06 & 19.13 & 13.85 & 18.51 & [16.85 20.17] \\
\hline \multirow{5}{*}{$\begin{array}{l}\text { Net crop income per unit } \\
\text { of labor }\end{array}$} & 5 [highest] & 9.39 & 24.80 & 22.51 & 22.91 & 24.30 & 20.81 & [ 18.64 22.98] \\
\hline & 4 & 11.80 & 27.68 & 26.22 & 29.14 & 60.35 & 30.87 & {$\left[\begin{array}{lll}27.83 & 33.92\end{array}\right]$} \\
\hline & 3 & 11.56 & 22.10 & 20.61 & 27.30 & 43.12 & 24.39 & {$\left[\begin{array}{lll}22.00 & 26.79\end{array}\right]$} \\
\hline & 2 & 15.73 & 18.08 & 21.98 & 33.73 & 45.86 & 27.55 & {$\left[\begin{array}{lll}22.54 & 32.55\end{array}\right]$} \\
\hline & 1 [lowest] & 14.28 & 20.62 & 26.95 & 21.14 & 12.57 & 19.18 & [17.33 21.03] \\
\hline \multirow{5}{*}{$\begin{array}{l}\text { Net farm income per } \\
\text { hectare owned }\end{array}$} & 5 [highest] & 46.75 & 80.66 & 83.66 & 59.52 & 69.76 & 68.22 & {$\left[\begin{array}{lll}60.99 & 75.46\end{array}\right]$} \\
\hline & 4 & 44.55 & 75.22 & 83.98 & 59.42 & 122.44 & 77.09 & {$\left[\begin{array}{ll}72.03 & 82.14\end{array}\right]$} \\
\hline & 3 & 30.71 & 44.24 & 54.45 & 46.86 & 77.78 & 50.25 & [ [46.52 53.99] \\
\hline & 2 & 30.51 & 31.54 & 46.03 & 45.51 & 58.48 & 43.02 & {$\left[\begin{array}{ll}39.32 & 46.71\end{array}\right]$} \\
\hline & 1 [lowest] & 25.13 & 31.81 & 35.61 & 21.16 & 14.91 & 25.85 & {$\left[\begin{array}{lll}23.78 & 27.92\end{array}\right]$} \\
\hline \multirow{5}{*}{$\begin{array}{l}\text { Net farm income per unit } \\
\text { of labor }\end{array}$} & 5 [highest] & 14.81 & 33.71 & 34.97 & 23.25 & 24.84 & 26.40 & [ $\left.\begin{array}{lll}23.16 & 29.64\end{array}\right]$ \\
\hline & 4 & 18.23 & 39.47 & 39.45 & 29.56 & 60.96 & 37.32 & {$\left[\begin{array}{ll}34.11 & 40.53\end{array}\right]$} \\
\hline & 3 & 15.10 & 27.77 & 28.68 & 27.67 & 44.10 & 28.21 & {$\left[\begin{array}{lll}25.67 & 30.75\end{array}\right]$} \\
\hline & 2 & 25.54 & 26.11 & 33.35 & 37.08 & 49.76 & 34.78 & {$\left[\begin{array}{ll}29.35 & 40.20\end{array}\right]$} \\
\hline & 1 [lowest] & 19.57 & 32.70 & 45.17 & 25.72 & 43.39 & 37.50 & {$\left[\begin{array}{lll}24.65 & 30.36\end{array}\right]$} \\
\hline \multirow{5}{*}{$\begin{array}{l}\text { Value of off-farm income } \\
\text { per adult equivalent }\end{array}$} & 5 [highest] & 7.84 & 9.18 & 13.36 & 13.86 & 19.34 & 12.72 & [ [11.52 13.91] \\
\hline & 4 & 8.75 & 11.86 & 19.91 & 23.91 & 41.46 & 21.23 & [ 18.33 24.14] \\
\hline & 3 & 6.68 & 9.34 & 14.25 & 17.03 & 22.99 & 13.86 & {$\left[\begin{array}{lll}12.21 & 15.50\end{array}\right]$} \\
\hline & 2 & 8.84 & 10.67 & 15.23 & 16.60 & 27.97 & 16.26 & {$\left[\begin{array}{ll}14.32 & 18.20\end{array}\right]$} \\
\hline & 1 [lowest] & 7.88 & 13.59 & 15.84 & 20.57 & 26.01 & 16.75 & {$\left[\begin{array}{ll}14.87 & 18.63\end{array}\right]$} \\
\hline \multirow{5}{*}{$\begin{array}{l}\text { Value of assets/wealth per } \\
\text { adult equivalent }\end{array}$} & 5 [highest] & 8.37 & 8.60 & 10.21 & 13.65 & 12.40 & 10.66 & {$\left[\begin{array}{lll}9.53 & 11.78\end{array}\right]$} \\
\hline & 4 & 11.14 & 12.02 & 15.55 & 27.10 & 29.91 & 19.18 & [ [ 16.33 22.03] \\
\hline & 3 & 9.06 & 9.14 & 15.26 & 18.54 & 24.58 & 15.10 & {$\left[\begin{array}{lll}13.44 & 16.75\end{array}\right]$} \\
\hline & 2 & 19.16 & 14.25 & 19.02 & 19.46 & 30.43 & 20.85 & [ 18.56 23.14] \\
\hline & 1 [lowest] & 22.20 & 26.31 & 43.95 & 49.35 & 57.12 & 39.59 & {$\left[\begin{array}{ll}35.21 & 43.96\end{array}\right]$} \\
\hline \multirow{5}{*}{$\begin{array}{l}\text { Household aggregate } \\
\text { annual income }\end{array}$} & 5 [highest] & 16.1 & 29.3 & 30.3 & 33.2 & 42.9 & 30.4 & {$\left[\begin{array}{lll}28.29 & 32.47\end{array}\right]$} \\
\hline & 4 & 19.1 & 34.6 & 46.1 & 51.7 & 93.9 & 49.2 & {$\left[\begin{array}{lll}45.09 & 53.25\end{array}\right]$} \\
\hline & 3 & 15.5 & 26.4 & 32.2 & 37.9 & 55.2 & 33.0 & {$\left[\begin{array}{lll}30.42 & 35.50\end{array}\right]$} \\
\hline & 2 & 22.4 & 24.4 & 34.0 & 39.8 & 62.8 & 37.6 & [34.25 40.91] \\
\hline & 1 [lowest] & 19.0 & 31.9 & 42.1 & 49.2 & 46.1 & 37.6 & {$\left[\begin{array}{lll}34.18 & 41.06\end{array}\right]$} \\
\hline
\end{tabular}

Source: Tegemeo institute rural household surveys

Notes: Population density quintiles are defined by ranking all households in the surveys by village-level population density and dividing them into five equal groups

to be an important measure of household livelihood, productive potential, and safety net.

Table 4 shows that households' asset wealth per adult equivalent has been consistently higher (more than twice) in households located in the low population density areas. Family size in adults and adult equivalents is almost the same across all five population density quintiles, meaning that asset wealth per household is also substantially higher on average in the low density areas. Conversely, aggregate household income tends to rise with population density, once again up to the fourth quintile, and thereafter starts to decline.

The bivariate relationships presented in Tables 3 and 4, while providing a fairly consistent picture, do not control for the effects of other variables affecting farm productivity, 
incomes and asset wealth. However, these relationships do lead to an important hypothesis for more rigorous analysis in the next section. Specifically, are there threshold effects of population density that cause input use intensity, productivity, and incomes to decline beyond a certain point? And if this is found to be the case, what are the causes of this threshold effect?

\section{Econometric results}

This section reports the main results from the econometric regressions of the impact of increasing population density on some selected indicators of farm productivity and welfare. We first discuss the estimates from the first-stage model of population density determinants, followed by the second-stage control function results.

Table 5 presents the first-stage results of the drivers of population density growth. The variable capturing potential soil quality is measured at three different levels, namely, the potential kilocalories obtainable from the $10 \mathrm{~km}^{2}$ location based on (i) existing cultivated land; (ii) existing cultivated land plus grasslands; and (iii) cultivated, grassland, and forest lands. The first and second indicators might reflect food production potential in the short- and medium-run, while the third indicator would reflect longer-term potential, and would obviously present major environmental tradeoffs. Generally the results shown in Table 5 indicate that the major determinants of population density in 2009 include distances to infrastructural facilities, the population of the location in prior decades, and area sizes; village-level rainfall quantities, rainfall variability and soil quality; as well as the agro-ecological zones where these villages are located. For example, if households in Location A are $1 \mathrm{~km}$ closer to motorable roads, water sources, and healthcare facilities than households in Location $\mathrm{B}$, the population density in Location $\mathrm{A}$ is estimated to be $0.32,0.57$ and $0.17 \%$ higher than in Location B. If Location A's long-run average annual rainfall is $100 \mathrm{~mm}$ higher than Location $\mathrm{B}$, the population density of Location $\mathrm{A}$ is estimated to be $10 \%$ higher than Location B. Increased rainfall variability is associated with lower population density. As expected, land quality as represented by the potential kilocalories obtainable from each $10 \mathrm{~km}^{2}$ pixel of cultivated land increases population density by $7.2 \%$.

Table 5 First-stage CRE estimation results for population density in 2009

\begin{tabular}{|c|c|c|c|c|c|c|}
\hline \multirow{2}{*}{$\begin{array}{l}\text { Dep. Variable: Log of village-level population } \\
\text { density for each household (persons per } \mathrm{km}^{2} \text { ) }\end{array}$} & \multicolumn{2}{|l|}{$[\mathrm{I}]$} & \multicolumn{2}{|l|}{ [II] } & \multicolumn{2}{|l|}{$[\mathrm{III}]$} \\
\hline & Coef. & S.E. & Coef. & S.E. & Coef. & S.E. \\
\hline Distance to motorable road ('00 km) & $-0.324^{* *}$ & 0.138 & $-0.324^{* *}$ & 0.138 & $-0.324^{* *}$ & 0.138 \\
\hline Distance to water source (' $00 \mathrm{~km})$ & $-0.571^{* *}$ & 0.268 & $-0.571^{* *}$ & 0.268 & $-0.571^{* *}$ & 0.268 \\
\hline Distance to health center ('00 km) & $-0.173^{* * *}$ & 0.059 & $-0.173^{* * *}$ & 0.059 & $-0.173^{* * *}$ & 0.059 \\
\hline Distance to electricity ('00 km) & $-0.247^{* * *}$ & 0.068 & $-0.247^{* * *}$ & 0.068 & $-0.247^{* * *}$ & 0.068 \\
\hline Distance to public telephone ('00 km) & $-0.383^{* * *}$ & 0.067 & $-0.383^{* * *}$ & 0.067 & $-0.383^{* * *}$ & 0.067 \\
\hline Population in 1969 ('000 persons) & $0.009^{* * *}$ & 0.001 & $0.010^{* * *}$ & 0.001 & $0.009^{* * *}$ & 0.001 \\
\hline Area in sq. $\mathrm{km}$ in 1969 & -0.001 & 0.002 & $0.001^{* * *}$ & 0.000 & $0.002^{* * *}$ & 0.000 \\
\hline Population in 1979 ('000 persons) & $-0.202^{* * *}$ & 0.018 & $-0.086^{* * *}$ & 0.019 & $-0.041^{* *}$ & 0.019 \\
\hline Area in sq. km in 1979 & $0.002^{* * *}$ & 0.000 & $0.002^{* * *}$ & 0.000 & $0.002^{* * *}$ & 0.000 \\
\hline Population in 1989 (‘000 persons) & $0.831^{* * *}$ & 0.036 & $0.677^{* * *}$ & 0.040 & $0.622^{* * *}$ & 0.043 \\
\hline Area in sq. km in 1989 & $-0.005^{* * *}$ & 0.001 & $-0.006^{* * *}$ & 0.001 & $-0.006^{* * *}$ & 0.001 \\
\hline Rainfall ('00 mm) & $0.098^{* * *}$ & 0.014 & $0.098^{* * *}$ & 0.014 & $0.098^{* * *}$ & 0.014 \\
\hline Rainfall stress & $-0.035^{* * *}$ & 0.003 & $-0.035^{* * *}$ & 0.003 & $-0.035^{* * *}$ & 0.003 \\
\hline \multicolumn{7}{|l|}{ Potential calories (trillion) from $10 \mathrm{~km}^{2}$ pixel: } \\
\hline _arable cultivated land & $0.072^{* * *}$ & 0.004 & - & - & - & - \\
\hline _arable cultivated and grasslands land & - & - & $0.027^{* * *}$ & 0.004 & - & - \\
\hline _arable cultivated, and grass and forest lands & - & - & - & - & -0.003 & 0.003 \\
\hline \multicolumn{7}{|l|}{ Agro ecological zone dummies included } \\
\hline Constant & $-1.816^{* * *}$ & 0.118 & $-2.697^{* * *}$ & 0.162 & $0.733^{* * *}$ & 0.274 \\
\hline Number of obs. & 4584 & & 4584 & & 4584 & \\
\hline Number of households & 1146 & & 1146 & & 1146 & \\
\hline R Squared & 0.986 & & 0.986 & & 0.986 & \\
\hline
\end{tabular}

Notes: All the time varying variables are lagged one survey period; $S . E=$ bootstrapped standard errors; $* * *=p<0.01, * *=p<0.05, *=p<0.1$ 
Next we present the second-stage control function regression results of the impact of increasing population density on selected agricultural production and household welfare outcomes. Because of space limitations, we focus on only a few outcome variables of interest. By including the agroecological zones among the other controls, the results presented in this section have a "within zone" interpretation. This means that the relationship between village population density and outcome variables hold constant the variation in the outcome variables that might occur due to differences in agro-ecological potential. The same holds true for unobserved time effects through the inclusion of survey year dummy variables. Since the third land quality variable was not statistically significant in the first stage, we present the results using the first two land potential variables only.
Landholding size and cropped area

Tables 6 and 7 regression results indicate that landholding sizes and area in hectares cultivated per adult equivalent in the main season decline with population density. Controlling for all other variables shown on Table 6, an increase in population density by 100 persons per $\mathrm{km}^{2}$ is associated with $9 \%$ smaller farm sizes. A similar increase in population density reduces area cropped per adult equivalent by about $8 \%$. These relationships are highly statistically significant. A more complete presentation of these relationships is revealed when we look at the postestimation simulations of the relationships between these outcome variables and population density, holding all other factors constant. Figure 4(a) and (b) show that landholding

Table 6 CRE estimation results of farm size per adult equivalent

\begin{tabular}{|c|c|c|c|c|c|c|}
\hline \multirow{2}{*}{$\begin{array}{l}\text { Dep. Variable: log of land holding (ha) } \\
\text { per adult equivalent }\end{array}$} & \multicolumn{3}{|l|}{$[\mathrm{I}]$} & \multicolumn{3}{|l|}{$[\mathrm{II}]$} \\
\hline & Coef. & S.E. & $\mathrm{P}>\mathrm{Z}$ & Coef. & S.E. & $\mathrm{P}>\mathrm{Z}$ \\
\hline Population density ('00persons $/ \mathrm{km}^{2}$ ) & -0.088 & 0.007 & 0.00 & -0.090 & 0.007 & 0.00 \\
\hline Distance to motorable road ('00 km) & -0.810 & 0.800 & 0.31 & -0.814 & 0.800 & 0.31 \\
\hline Distance to water source ('00 km) & 0.300 & 0.200 & 0.14 & 0.300 & 0.200 & 0.13 \\
\hline Distance to healthcare centre ('00 km) & -0.468 & 0.373 & 0.21 & -0.471 & 0.374 & 0.21 \\
\hline Distance to electricity supply ('00 km) & -0.193 & 0.353 & 0.59 & -0.197 & 0.353 & 0.58 \\
\hline Ag. wage rate ('00 Ksh.)- village median & -0.024 & 0.087 & 0.78 & -0.024 & 0.086 & 0.78 \\
\hline Land rent ('000 Ksh.)- village median & -0.005 & 0.002 & 0.01 & -0.005 & 0.002 & 0.01 \\
\hline DAP price (Ksh.)- village median & -0.017 & 0.005 & 0.00 & -0.017 & 0.005 & 0.00 \\
\hline Rainfall ('00 mm) & 0.030 & 0.019 & 0.12 & 0.029 & 0.019 & 0.13 \\
\hline Rainfall stress & -0.178 & 0.226 & 0.43 & -0.171 & 0.226 & 0.45 \\
\hline Calories from arable cultivated land (trillions $/ 10 \mathrm{~km}^{2}$ ) & 0.010 & 0.005 & 0.04 & - & - & - \\
\hline $\begin{array}{l}\text { Calories from arable cultivated and grasslands } \\
\text { land (trillions } / 10 \mathrm{~km}^{2} \text { ) }\end{array}$ & - & - & - & -0.014 & 0.003 & 0.00 \\
\hline \multicolumn{7}{|l|}{ Zone dummies (Central highland is the base) } \\
\hline Eastern lowlands & -0.149 & 0.096 & 0.12 & 0.129 & 0.102 & 0.20 \\
\hline Western lowlands & 0.056 & 0.090 & 0.54 & 0.301 & 0.099 & 0.00 \\
\hline Western transitional & -0.017 & 0.099 & 0.86 & 0.108 & 0.098 & 0.27 \\
\hline High potential maize & -0.006 & 0.065 & 0.93 & 0.147 & 0.072 & 0.04 \\
\hline Western highlands & 0.087 & 0.083 & 0.30 & 0.188 & 0.085 & 0.03 \\
\hline Marginal rain shadow & -0.588 & 0.093 & 0.00 & -0.399 & 0.095 & 0.00 \\
\hline \multicolumn{7}{|l|}{ Survey year dummies (year 2010 is the base) } \\
\hline year 2000 & -0.017 & 0.031 & 0.58 & -0.017 & 0.031 & 0.59 \\
\hline year 2004 & 0.042 & 0.041 & 0.31 & 0.041 & 0.041 & 0.31 \\
\hline year 2007 & 0.229 & 0.067 & 0.00 & 0.229 & 0.067 & 0.00 \\
\hline Residuals from first stage regression & 0.089 & 0.024 & 0.00 & 0.092 & 0.024 & 0.00 \\
\hline Constant & 1.361 & 0.365 & 0.00 & 1.546 & 0.364 & 0.00 \\
\hline Observations & 5730 & & & & 5730 & \\
\hline Households & 1146 & & & & 1146 & \\
\hline R-square & 0.735 & & & 0.735 & & \\
\hline
\end{tabular}

Notes: All the time varying variables are lagged one survey period; S.E bootstrapped standard errors; p-score is the measure of statistical significance 
Table 7 CRE estimation results of hectares under crop per adult equivalent

Dep. Variable: $\log$ of crop hectarage per adult equivalent

\begin{tabular}{|c|c|c|c|c|c|c|}
\hline & & \\
\hline & Coef. & S.E. & $\mathrm{P}>\mathrm{Z}$ & Coef. & S.E. & $\mathrm{P}>\mathrm{z}$ \\
\hline Population density ('00 persons $/ \mathrm{km}^{2}$ ) & -0.080 & 0.007 & 0.00 & -0.084 & 0.007 & 0.00 \\
\hline Distance to motorable road ('00 km) & -0.875 & 0.355 & 0.01 & -0.879 & 0.355 & 0.01 \\
\hline Distance to water source ('00 km) & 0.165 & 0.166 & 0.32 & 0.166 & 0.166 & 0.32 \\
\hline Distance to healthcare centre ('00 km) & -0.617 & 0.802 & 0.44 & -0.621 & 0.802 & 0.44 \\
\hline Distance to electricity supply ('00 km) & 0.200 & 0.348 & 0.57 & 0.194 & 0.347 & 0.58 \\
\hline Ag. wage rate ('00 Ksh.)- village median & -0.155 & 0.089 & 0.08 & -0.154 & 0.089 & 0.08 \\
\hline Land rent ('000 Ksh.)- village median & -0.002 & 0.002 & 0.24 & -0.002 & 0.002 & 0.24 \\
\hline DAP price (Ksh.)- village median & -0.009 & 0.005 & 0.07 & -0.009 & 0.005 & 0.07 \\
\hline Rainfall ('00 mm) & 0.038 & 0.020 & 0.06 & 0.037 & 0.020 & 0.07 \\
\hline Rainfall stress & -0.280 & 0.235 & 0.23 & -0.271 & 0.235 & 0.25 \\
\hline Calories from arable cultivated land (trillions $/ 10 \mathrm{~km}^{2}$ ) & 0.004 & 0.005 & 0.50 & - & - & - \\
\hline $\begin{array}{l}\text { Calories from arable cultivated and grasslands } \\
\text { land (trillions } / 10 \mathrm{~km}^{2} \text { ) }\end{array}$ & - & - & - & -0.013 & 0.003 & 0.00 \\
\hline \multicolumn{7}{|l|}{ Zone dummies (Central highland is the base) } \\
\hline Eastern lowlands & 0.096 & 0.101 & 0.34 & 0.314 & 0.102 & 0.00 \\
\hline Western lowlands & 0.037 & 0.092 & 0.68 & 0.244 & 0.100 & 0.02 \\
\hline Western transitional & -0.070 & 0.100 & 0.48 & 0.019 & 0.098 & 0.85 \\
\hline High potential maize & -0.186 & 0.067 & 0.01 & -0.054 & 0.073 & 0.46 \\
\hline Western highlands & 0.013 & 0.085 & 0.88 & 0.097 & 0.086 & 0.26 \\
\hline Marginal rain shadow & -0.802 & 0.082 & 0.00 & -0.646 & 0.086 & 0.00 \\
\hline \multicolumn{7}{|l|}{ Survey year dummies (year 2010 is the base) } \\
\hline year 2000 & 0.076 & 0.034 & 0.02 & 0.076 & 0.034 & 0.02 \\
\hline year 2004 & 0.112 & 0.042 & 0.01 & 0.112 & 0.042 & 0.01 \\
\hline year 2007 & 0.210 & 0.063 & 0.00 & 0.209 & 0.063 & 0.00 \\
\hline Residuals from first stage regression & 0.050 & 0.025 & 0.04 & 0.055 & 0.025 & 0.03 \\
\hline Constant & -0.191 & 0.371 & 0.61 & 0.071 & 0.375 & 0.85 \\
\hline Observations & 5730 & & & & 5730 & \\
\hline Households & 1146 & & & & 1146 & \\
\hline R-square & 0.659 & & & 0.659 & & \\
\hline
\end{tabular}

Notes: All the time varying variables are lagged one survey period; S.E bootstrapped standard errors; p-score is the measure of statistical significance

size and area cultivated per adult equivalent varies inversely with population density.

Input use intensity

Table 8 presents results on the cost of purchased inputs per hectare (fertilizers, seeds, hired labor, and land preparation costs), which is an indication of land intensification. The results show that the intensity of purchased inputs per hectare is a non-linear concave function of population density. Input intensity rises with population density to around 650 persons per $\mathrm{km} 2$; beyond this population density threshold, input intensification declines. Further, the intensity of purchased input use rises as land rental rates rise, and declines with increased distances to motorable roads, signalling increased input costs. The intensity of purchased input use also declines as we move from the relatively high-rainfall Central Highlands region (base region) to the more semi-arid lowlands.

Figure 4(c) and (d) show the simulated relationship between input use intensity on the $y$-axis and population density on the $\mathrm{x}$-axis, controlling for all the other variables. The results show that both fertilizer use and the use of all purchased inputs per hectare is an increasing function of the population density up to roughly 660 persons per $\mathrm{km}^{2}$, and then declines beyond that. Slightly less than $20 \%$ of the farm households in the sample are currently beyond this threshold (Fig. 4c). As shown in Fig. 4d, the general input use intensity starts to decline somewhere after 475 persons per $\mathrm{km}^{2}$; about $35 \%$ of the households in the sample live in villages beyond this population density threshold. 
(a) Land holding by population density

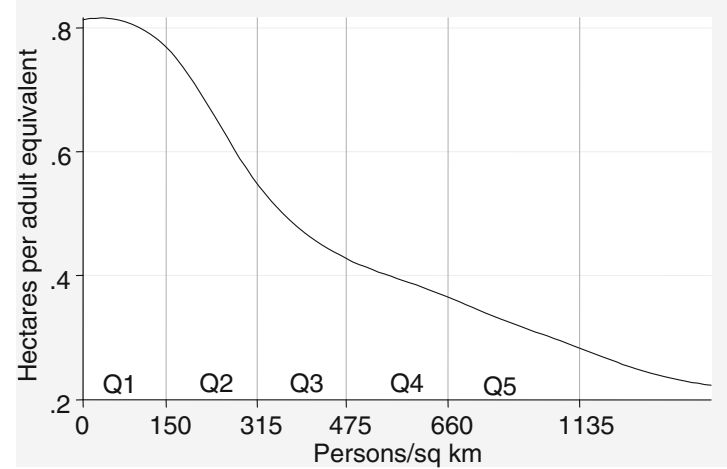

(c) Intensity of fertilizer input use per hectare

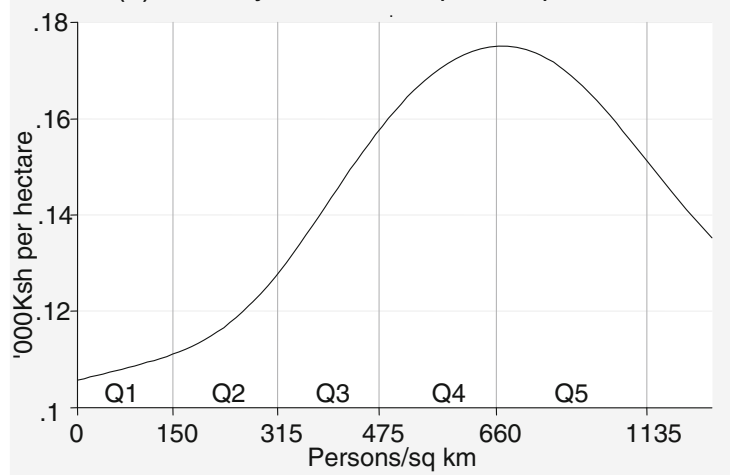

(e) Net farm income per hectare

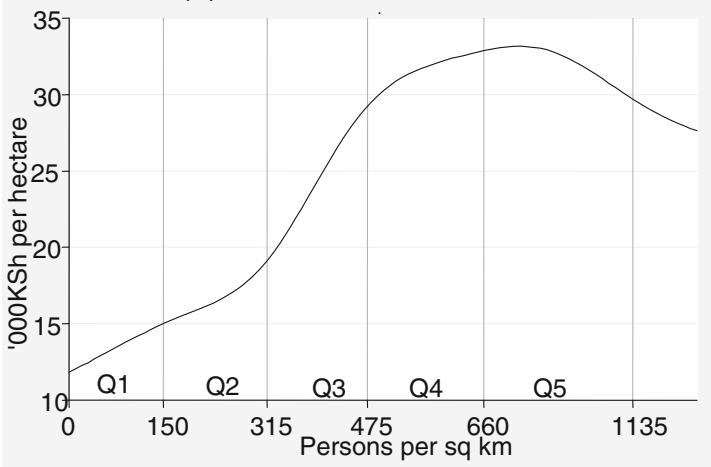

(g) Household asset value per adult equivalent

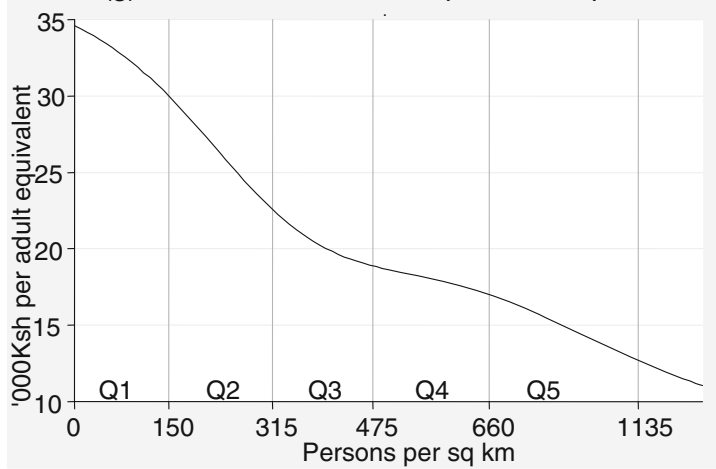

(b) Area under crop by population density

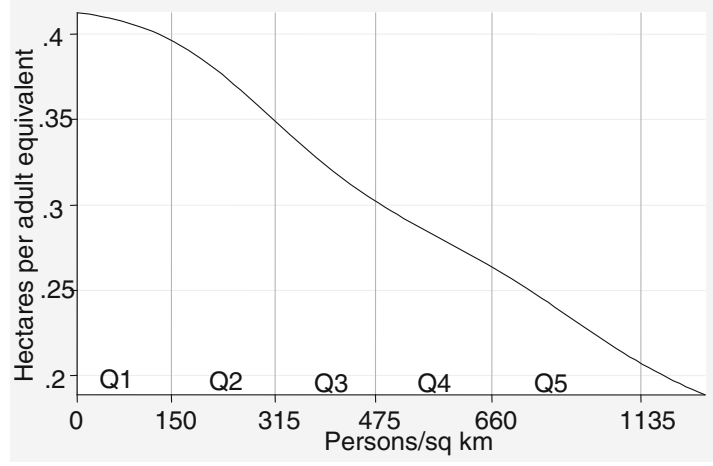

(d) Intensity of cash input use per hectare

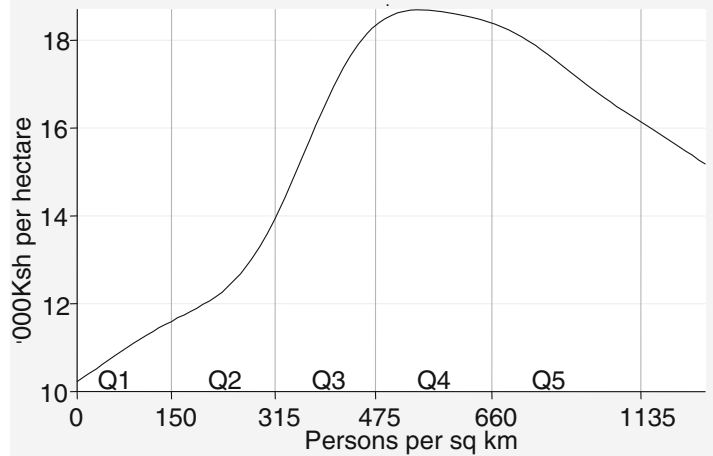

(f) Net farm income per adult equivalent

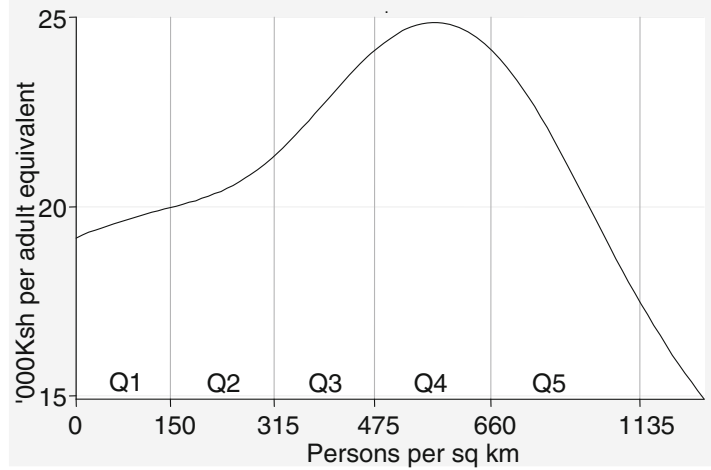

(h) Total household income per adult equivalent

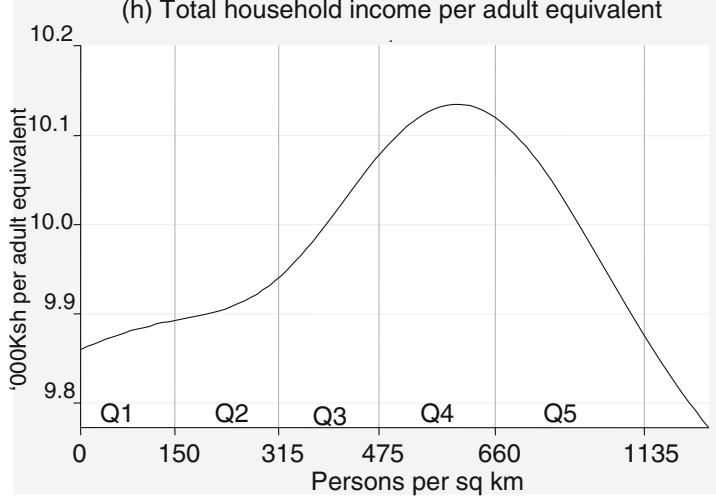

Fig. 4 Simulations from the econometric results showing the relationship between population density and variables of interest 
Table 8 CRE estimation results for intensity of cash input use per hectare

Dep. Variable: log of cost of purchased inputs (KSh) per ha

\begin{tabular}{l}
\hline Population density ('00 persons $/ \mathrm{km}^{2}$ ) \\
Population density square \\
Distance to motorable road ('00 km) \\
Distance to water source ('00 km) \\
Distance to healthcare centre ('00 km) \\
Distance to electricity supply ('00 km) \\
Ag. wage rate ('00 Ksh.)- village median \\
Land rent ('000 Ksh.)- village median \\
DAP price (Ksh.)- village median \\
Rainfall ('00 mm) \\
Rainfall stress
\end{tabular}

Calories from arable cultivated land (trillions $/ 10 \mathrm{~km}^{2}$ )

Calories from arable cultivated and grasslands land (trillions $/ 10 \mathrm{~km}^{2}$ )

Zone dummies (Central highland is the base)

Eastern lowlands
Western lowlands
Western transitional
High potential maize
Western highlands
Marginal rain shadow
Survey year dummies (year 2010 is the
year 2000
year 2004
year 2007
Residuals from first stage regression
Square of residuals
Constant
Observations
Households
R-square

[I]

Coef.

0.213

$-0.017$

$-0.886$

$-0.302$

$-0.501$

$-0.381$

0.080

0.004

0.007

$-0.031$

$-0.668$

$-0.054$

$-$

\begin{tabular}{llllll}
-0.635 & 0.108 & 0.00 & -0.028 & 0.116 & 0.81 \\
-1.412 & 0.111 & 0.00 & -0.716 & 0.118 & 0.00 \\
0.028 & 0.117 & 0.81 & 0.173 & 0.114 & 0.13 \\
-0.074 & 0.079 & 0.35 & 0.332 & 0.081 & 0.00 \\
-0.498 & 0.096 & 0.00 & -0.357 & 0.095 & 0.00 \\
-0.015 & 0.089 & 0.86 & 0.382 & 0.090 & 0.00 \\
& & & & & \\
0.245 & 0.038 & 0.00 & 0.262 & 0.038 & 0.00 \\
0.137 & 0.048 & 0.00 & 0.163 & 0.047 & 0.00 \\
0.405 & 0.076 & 0.00 & 0.434 & 0.076 & 0.00 \\
0.085 & 0.037 & 0.02 & 0.076 & 0.037 & 0.04 \\
-0.070 & 0.019 & 0.00 & -0.049 & 0.019 & 0.01 \\
4.956 & 0.419 & 0.00 & 7.261 & 0.422 & 0.00 \\
5730 & & & & 5730 & \\
1146 & & & & 1146 & \\
0.630 & & & & 0.626 & \\
\hline
\end{tabular}

Notes: All the time varying variables are lagged one survey period; S.E bootstrapped standard errors; p-score is the measure of statistical significance

What would explain these threshold effects? Market participation studies consistently show that farm sales are related to farm size (Barrett 2008). If farm sizes decline beyond a given point due to sub-division and land fragmentation caused by population pressures, households are less likely to generate the cash from crop sales that would allow them to purchase modern productivity-enhancing inputs. Less intensive input use then reinforces small farms' difficulties in producing a surplus. Furthermore, access to farm credit also tends to be restricted for farmers with limited land and other assets that could otherwise act as collateral. For these reasons, we feel that population density threshold effects are very plausible and may explain why a number of important farm productivity indicators tend to decline beyond a certain level of population density.

Household farm income

Tables 9 and 10 present the regression on net farm incomes per hectare and per adult equivalent, respectively. The CRE model estimates show that net farm incomes per hectare increase with population density up to about 680 persons per $\mathrm{km}^{2}$, but fall off slightly thereafter. Net farm incomes per adult equivalent, by contrast, shows a more sharp decline at a lower population density threshold of about 550 persons per $\mathrm{km}^{2}$, 
Table 9 CRE estimation results for value of net farm income per hectare owned

Dep. Variable: log of net farm income (KSh)

per hectare owned

\begin{tabular}{|c|c|c|c|c|c|c|}
\hline & & \\
\hline & Coef. & S.E. & $\mathrm{P}>\mathrm{Z}$ & Coef. & S.E. & $\mathrm{P}>\mathrm{z}$ \\
\hline Population density (' 00 persons $/ \mathrm{km}^{2}$ ) & 0.321 & 0.047 & 0.00 & 0.258 & 0.055 & 0.00 \\
\hline Population density square & -0.030 & 0.005 & 0.00 & -0.024 & 0.005 & 0.00 \\
\hline Distance to motorable road ('00 km) & -0.016 & 0.009 & 0.07 & -0.016 & 0.009 & 0.08 \\
\hline Distance to water source (' $00 \mathrm{~km}$ ) & 0.001 & 0.004 & 0.88 & 0.001 & 0.004 & 0.88 \\
\hline Distance to healthcare centre (' $00 \mathrm{~km}$ ) & -0.017 & 0.015 & 0.26 & -0.017 & 0.015 & 0.26 \\
\hline Distance to electricity supply ('00 km) & 0.005 & 0.008 & 0.57 & 0.005 & 0.008 & 0.55 \\
\hline Ag. wage rate ('00 Ksh.)- village median & -0.604 & 0.214 & 0.01 & -0.596 & 0.215 & 0.01 \\
\hline Land rent ('000 Ksh.)- village median & -0.018 & 0.004 & 0.00 & -0.018 & 0.004 & 0.00 \\
\hline DAP price (Ksh.)- village median & -0.007 & 0.013 & 0.60 & -0.007 & 0.013 & 0.59 \\
\hline Rainfall ('00 mm) & 0.066 & 0.022 & 0.00 & 0.063 & 0.022 & 0.00 \\
\hline Rainfall stress & -0.018 & 0.006 & 0.00 & -0.018 & 0.006 & 0.00 \\
\hline Calories from arable cultivated land (trillions $/ 10 \mathrm{~km}^{2}$ ) & 0.013 & 0.012 & 0.28 & - & - & - \\
\hline $\begin{array}{l}\text { Calories from arable cultivated and grasslands } \\
\text { land (trillions } / 10 \mathrm{~km}^{2} \text { ) }\end{array}$ & - & - & - & -0.024 & 0.008 & 0.00 \\
\hline \multicolumn{7}{|l|}{ Zone dummies (Central highland is the base) } \\
\hline Eastern lowlands & -0.425 & 0.224 & 0.06 & 0.084 & 0.245 & 0.73 \\
\hline Western lowlands & -2.466 & 0.195 & 0.00 & -2.046 & 0.236 & 0.00 \\
\hline Western transitional & -2.248 & 0.238 & 0.00 & -2.011 & 0.246 & 0.00 \\
\hline High potential maize & -1.725 & 0.177 & 0.00 & -1.487 & 0.190 & 0.00 \\
\hline Western highlands & -1.642 & 0.212 & 0.00 & -1.538 & 0.218 & 0.00 \\
\hline Marginal rain shadow & -1.127 & 0.253 & 0.00 & -0.831 & 0.257 & 0.00 \\
\hline \multicolumn{7}{|l|}{ Survey year dummies (year 2010 is the base) } \\
\hline year 2000 & 0.015 & 0.085 & 0.86 & 0.014 & 0.085 & 0.87 \\
\hline year 2004 & -0.077 & 0.109 & 0.48 & -0.074 & 0.109 & 0.50 \\
\hline year 2007 & 0.267 & 0.163 & 0.10 & 0.268 & 0.163 & 0.10 \\
\hline Residuals from first stage regression & 0.150 & 0.090 & 0.09 & 0.135 & 0.090 & 0.13 \\
\hline Square of residuals & -0.031 & 0.114 & 0.79 & -0.045 & 0.113 & 0.69 \\
\hline Constant & 7.100 & 0.986 & 0.00 & 7.360 & 1.019 & 0.00 \\
\hline Observations & 5730 & & & & 5730 & \\
\hline Households & 1146 & & & & 1146 & \\
\hline R-square & 0.274 & & & & 0.272 & \\
\hline
\end{tabular}

Notes: All the time varying variables are lagged one survey period; S.E bootstrapped standard errors; p-score is the measure of statistical significance

following a pattern very similar to input use intensification. All of these relationships are highly statistically significant. The subsequent post estimation simulation results are presented in Fig. 4(e) and (f). The results also show that lower distances to motorable roads are associated with higher farm incomes. Higher farm wage rates, land rental rates, and fertilizer prices are all significantly associated with lower farm incomes per adult equivalent (Table 10); only the first two input prices are significantly associated with farm incomes per hectare. As expected, increased rainfall level (variability) is found to be associated with higher (lower) farm incomes.
These results apply to both crop and animal operations; results are similar when the dependent variable is net crop income or net animal income. Intensive animal operations such as zero grazing dairy is significantly more commonly practiced in the high density areas, producing higher levels of animal income per land unit. However, this is only possible up to a certain population density level, beyond which, the land sizes become too small for economical operations. This evidence of a decline in partial land productivity at high levels of rural population density is alarming, as it implies that land productivity growth cannot be sustained simply by using other inputs more intensively per unit of land. Animal income and 
Table 10 CRE estimation results of value of net farm income per adult equivalent

Dep. Variable: log of net farm income (KSh)

per adult equivalent

$[\mathrm{I}]$

\begin{tabular}{lllllll}
\hline Coef. & S.E. & P $>\mathrm{z}$ & & Coef. & S.E. & $\mathrm{P}>\mathrm{z}$ \\
\hline 0.208 & 0.046 & 0.00 & 0.103 & 0.055 & 0.05 \\
-0.028 & 0.005 & 0.00 & -0.018 & 0.005 & 0.00 \\
-0.021 & 0.009 & 0.02 & -0.021 & 0.009 & 0.02 \\
0.001 & 0.004 & 0.96 & 0.001 & 0.004 & 0.95 \\
-0.014 & 0.014 & 0.32 & -0.014 & 0.014 & 0.32 \\
0.004 & 0.007 & 0.58 & 0.004 & 0.007 & 0.54 \\
-0.651 & 0.204 & 0.00 & -0.634 & 0.204 & 0.00 \\
-0.021 & 0.004 & 0.00 & -0.021 & 0.004 & 0.00 \\
-0.024 & 0.012 & 0.05 & -0.024 & 0.012 & 0.04 \\
0.069 & 0.020 & 0.00 & 0.066 & 0.020 & 0.00 \\
-0.025 & 0.005 & 0.00 & -0.025 & 0.005 & 0.00 \\
0.022 & 0.012 & 0.07 & - & - & - \\
- & - & - & -0.041 & 0.008 & 0.00
\end{tabular}

\begin{tabular}{llllll}
-0.684 & 0.215 & 0.00 & 0.181 & 0.241 & 0.45 \\
-2.391 & 0.179 & 0.00 & -1.675 & 0.221 & 0.00 \\
-2.216 & 0.226 & 0.00 & -1.820 & 0.235 & 0.00 \\
-1.794 & 0.166 & 0.00 & -1.390 & 0.180 & 0.00 \\
-1.516 & 0.198 & 0.00 & -1.338 & 0.203 & 0.00 \\
-1.692 & 0.226 & 0.00 & -1.190 & 0.232 & 0.00 \\
& & & & & \\
0.068 & 0.077 & 0.38 & 0.068 & 0.077 & 0.38 \\
0.012 & 0.102 & 0.91 & 0.016 & 0.102 & 0.87 \\
0.522 & 0.146 & 0.00 & 0.524 & 0.146 & 0.00 \\
0.237 & 0.081 & 0.00 & 0.212 & 0.082 & 0.01 \\
0.110 & 0.111 & 0.32 & 0.090 & 0.110 & 0.42 \\
9.015 & 0.928 & 0.00 & 9.505 & 0.949 & 0.00 \\
5730 & & & & 5730 & \\
1146 & & & & 1146 & \\
0.400 & & & & 0.399 & \\
\hline
\end{tabular}

Notes: All the time varying variables are lagged one survey period; S.E bootstrapped standard errors; p-score is the measure of statistical significance

milk production also show a similar plateau and drop off at 650 persons per $\mathrm{km}^{2}$. As Kenya's rural population continues to grow, ${ }^{7}$ a greater proportion of the country's rural areas will soon reach this apparent land productivity plateau. Currently, most of the districts with mean population density greater than

\footnotetext{
${ }^{7}$ Fortunately, Kenya's rural population growth rate has been declining from its peak at $3.4 \%$ in 1984 to $2.3 \%$ in 2008 according to the 2009 official census.
}

650 persons per $\mathrm{km}^{2}$ are in Nyanza and Western Provinces, with most in Central Province approaching this threshold. ${ }^{8}$ In 2009, the 16 districts with greater than 650 persons per $\mathrm{km}^{2}$ accounted for $14.2 \%$ of Kenya's rural population and $1.3 \%$ of its rural land.

\footnotetext{
${ }^{8}$ These districts include Emuhaya, Hamisi, Vihiga, Kisii Central, Gucha, Manga, Nyamira, Githunguri (in Central Province), Gucha South, Masaba, Kakamega South, and Kisii South. Median farm size in these districts covered in the Tegemeo sample (Vihiga, Kisii, and Kakamega) is 0.94 ha per farm.
} 
Table 11 CRE estimation results for household assets value per adult equivalent

\begin{tabular}{|c|c|c|c|c|c|c|}
\hline \multirow[t]{2}{*}{ Dep. Variable: $\log$ of the household assets value (KSh) } & \multicolumn{3}{|l|}{$[\mathrm{I}]$} & \multicolumn{3}{|l|}{$[\mathrm{II}]$} \\
\hline & Coef. & S.E. & $\mathrm{P}>\mathrm{Z}$ & Coef. & S.E. & $\mathrm{P}>\mathrm{Z}$ \\
\hline Population density ('00 persons $/ \mathrm{km}^{2}$ ) & -0.071 & 0.016 & 0.00 & -0.069 & 0.016 & 0.00 \\
\hline Distance to motorable road ('00 km) & -0.011 & 0.014 & 0.44 & -0.011 & 0.014 & 0.44 \\
\hline Distance to water source ('00 km) & -0.002 & 0.004 & 0.55 & -0.002 & 0.004 & 0.55 \\
\hline Distance to healthcare centre ('00 km) & -0.006 & 0.007 & 0.37 & -0.006 & 0.007 & 0.37 \\
\hline Distance to electricity supply (' $00 \mathrm{~km}$ ) & -0.002 & 0.008 & 0.77 & -0.002 & 0.008 & 0.77 \\
\hline Ag. wage rate ('00 Ksh.)- village median & -0.419 & 0.198 & 0.04 & -0.419 & 0.198 & 0.03 \\
\hline Land rent ('000 Ksh.)- village median & -0.010 & 0.004 & 0.01 & -0.010 & 0.004 & 0.01 \\
\hline DAP price (Ksh.)- village median & -0.022 & 0.014 & 0.11 & -0.022 & 0.014 & 0.11 \\
\hline Rainfall ('00 mm) & 0.047 & 0.017 & 0.01 & 0.047 & 0.017 & 0.01 \\
\hline Rainfall stress & -0.124 & 0.048 & 0.01 & -0.123 & 0.048 & 0.01 \\
\hline Calories from arable cultivated land (trillions $/ 10 \mathrm{~km}^{2}$ ) & 0.050 & 0.013 & 0.00 & - & - & - \\
\hline $\begin{array}{l}\text { Calories from arable cultivated and grasslands } \\
\text { land (trillions } / 10 \mathrm{~km}^{2} \text { ) }\end{array}$ & - & - & - & -0.025 & 0.007 & 0.00 \\
\hline \multicolumn{7}{|l|}{ Zone dummies (Central highland is the base) } \\
\hline Eastern lowlands & 0.691 & 0.089 & 0.00 & 0.691 & 0.089 & 0.00 \\
\hline Western lowlands & 0.919 & 0.110 & 0.00 & 0.918 & 0.110 & 0.00 \\
\hline Western transitional & 0.865 & 0.184 & 0.00 & 0.864 & 0.184 & 0.00 \\
\hline High potential maize & -1.324 & 0.206 & 0.00 & -0.593 & 0.223 & 0.01 \\
\hline Western highlands & -1.499 & 0.182 & 0.00 & -0.934 & 0.209 & 0.00 \\
\hline Marginal rain shadow & -1.901 & 0.179 & 0.00 & -1.526 & 0.165 & 0.00 \\
\hline \multicolumn{7}{|l|}{ Survey year dummies (year 2010 is the base) } \\
\hline year 2000 & -0.880 & 0.165 & 0.00 & -0.425 & 0.181 & 0.02 \\
\hline year 2004 & 0.138 & 0.092 & 0.13 & 0.137 & 0.091 & 0.13 \\
\hline year 2007 & 0.000 & 0.323 & 1.00 & 0.008 & 0.323 & 0.98 \\
\hline Residuals from first stage regression & 14.399 & 0.876 & 0.00 & 14.222 & 0.889 & 0.00 \\
\hline Constant & 1.361 & 0.365 & 0.00 & 1.546 & 0.364 & 0.00 \\
\hline Observations & 5730 & & & & 5730 & \\
\hline Households & 1146 & & & & 1146 & \\
\hline R-square & 0.639 & & & & 0.640 & \\
\hline
\end{tabular}

Notes: All the time varying variables are lagged one survey period; S.E bootstrapped standard errors; $\mathrm{p}$-score is the measure of statistical significance

Household asset wealth and incomes

Lastly, we discuss the relationships between population density and household asset wealth (Table 11) and total income per adult equivalent (Table 12). The results show an unambiguously and statistically significant negative relationship between household assets and population density (Table 11). Holding constant differences in asset wealth due to differences in infrastructural conditions, input prices, rainfall quantity and variability, soil quality, agroecological potential and survey years, we find that an increase of 100 persons per $\mathrm{km}^{2}$ is associated with a $7 \%$ decline in asset wealth per adult equivalent. This relationship is shown graphically in Fig. 4(g).
By contrast, total household incomes tend to rise with population density up to a now familiar threshold and thereafter decline (Table 12). The post estimation simulations show a clearer picture of these relationships. Total household incomes per adult equivalent rise with population density up to roughly 550 persons per $\mathrm{km}^{2}$ and decline thereafter, as shown in Fig. 4(h). Higher population density is associated with smaller farm sizes, other factors constant. Small farm sizes may be associated with diseconomies of scale in input acquisition. Other factors constant, smaller farm sizes reduce the potential to produce surpluses, which may in turn cause capital constraints that impede the demand for purchased inputs and new technologies. These processes may explain why our results indicate adverse effects of population density, 
Table 12 CRE estimation results for household income per adult equivalent

Dep. Variable: log of household income (KSh)

per adult equivalent
[I]

Coef.

Population density ('00 persons $/ \mathrm{km}^{2}$ )

Population density square

Distance to motorable road ('00 km)

Distance to water source ('00 km)

Distance to healthcare centre ('00 km)

Distance to electricity supply ('00 km)

Ag. wage rate ('00 Ksh.)- village median

Land rent ('000 Ksh.)- village median

DAP price (Ksh.)- village median

Rainfall ('00 mm)

Rainfall stress

Calories from arable cultivated land (trillions $/ 10 \mathrm{~km}^{2}$ )

Calories from arable cultivated and grasslands

land (trillions $/ 10 \mathrm{~km}^{2}$ )

Zone dummies (Central highland is the base)

Eastern lowlands

Western lowlands

Western transitional

High potential maize

Western highlands

Marginal rain shadow

Survey year dummies (year 2010 is the base)

year 2000

year 2004

year 2007

Residuals from first stage regression

Square of residuals

Constant

Observations

Households

R-square

[II]

\begin{tabular}{lll}
\hline Coef. & S.E. & $\mathrm{P}>\mathrm{z}$ \\
0.139 & 0.051 & 0.01 \\
-0.015 & 0.005 & 0.00 \\
-0.019 & 0.014 & 0.19 \\
0.001 & 0.004 & 0.90 \\
-0.002 & 0.008 & 0.79 \\
0.009 & 0.010 & 0.37 \\
-0.453 & 0.181 & 0.01 \\
-0.006 & 0.003 & 0.05 \\
-0.023 & 0.011 & 0.04 \\
0.001 & 0.000 & 0.00 \\
-1.036 & 0.463 & 0.03 \\
- & - & - \\
-0.009 & 0.008 & 0.28
\end{tabular}

$\begin{array}{llllll}-0.775 & 0.218 & 0.00 & -0.315 & 0.244 & 0.20 \\ -1.871 & 0.178 & 0.00 & -1.572 & 0.215 & 0.00 \\ -1.487 & 0.191 & 0.00 & -1.232 & 0.194 & 0.00 \\ -0.918 & 0.138 & 0.00 & -0.760 & 0.151 & 0.00 \\ -1.108 & 0.163 & 0.00 & -1.028 & 0.163 & 0.00 \\ -0.910 & 0.247 & 0.00 & -0.667 & 0.250 & 0.01 \\ & & & & & \\ 0.178 & 0.071 & 0.01 & 0.171 & 0.071 & 0.02 \\ 0.485 & 0.084 & 0.00 & 0.480 & 0.084 & 0.00 \\ 0.830 & 0.132 & 0.00 & 0.832 & 0.132 & 0.00 \\ -0.045 & 0.070 & 0.52 & -0.061 & 0.070 & 0.39 \\ -0.033 & 0.098 & 0.74 & -0.058 & 0.098 & 0.55 \\ 10.458 & 0.758 & 0.00 & 9.973 & 0.767 & 0.00 \\ 5730 & & & & 5730 & \\ 1146 & & & & 1146 & \\ 0.412 & & & & 0.412 & \end{array}$

Notes: All the time varying variables are lagged one survey period; S.E bootstrapped standard errors; p-score is the measure of statistical significance

beyond some threshold, on indicators of farm intensification, farm income per unit of labor, and wealth.

\section{Conclusions and implications for institutional reform}

This study is motivated by the need to understand the nature and magnitude of emerging land constraints in African agriculture, the possible impacts of status-quo policies and institutions on food security and poverty, and the potential for institutional reforms to address these challenges.

These three main issues are addressed based on the case of Kenya. First, we explore the nature and magnitude of emerging land constraints for smallholder farmers with increasing population density. Evidence indicates that smallholder landholding sizes are gradually declining in Kenya as in much of sub-Saharan Africa. Two main reasons are advanced. First, arable land in some regions remains underutilized because it has yet to receive the requisite public investment in physical infrastructure to raise its economic value and attract migration into the areas. For example, the lower-elevation areas of Eastern Province could benefit greatly from harnessing the irrigation potential from the various rivers flowing from the Central Highlands. Other public investments (e.g., roads, electrification, schools, health facilities) and services could raise the economic value of 
surrounding farmland and thereby attract migration and settlement in these areas (Jayne et al. 2009). Second, and of major importance in Kenya, has been the post-independence continuation of colonial tenure systems vesting unutilized lands (which may nevertheless have customary authority claimants) in the hands of the state. Much of Kenya's arable land has been and continues to be allocated by the state to local elites and foreign investors. Meanwhile, some smallholder farming areas are facing emerging land constraints borne of steady rural population growth since independence. An important literature in Kenya has documented the rapacious disempowerment of local communities to access land, first by the colonialists and later by the successive postcolonial governments (Juma 1996; Kanyinga 1998; OkothOgendo 1976 and 1999). The colonization of Kenya and its enduring impacts on current landholding arrangements are well documented. The several post-independence Kenyan governments have largely retained the same institutions despite recognizing the importance of land rights and even elevating it to a crucial post-independence challenge (Republic of Kenya 1965). Inequalities in land ownership have persisted in spite of the existence of large tracts of underutilized land, even in high potential agricultural areas. While the modes of land access were primarily through inheritance and the market, access to public land has been a major instrument of patronage favoring the political elite. (Namwaya 2004). ${ }^{9}$ For these reasons, it is perhaps not surprising that median farm sizes are quite small and declining for a large proportion of the smallholder population, while large tracts of land in other parts of the country continue to be allocated by the state to local elites and foreign investors.

The second objective of the article was to examine the ways in which densely populated smallholder farming areas are evolving and to assess the implications for an inclusive smallholder-led development strategy. The evidence presented in sections "Descriptive results" and "Econometric results" paints a picture of rising strain on rural livelihoods in the densely populated rural areas due to land pressures and declining farm sizes. The value of farm income per unit labor tends to rise with population density up to about 600 persons per $\mathrm{km}^{2}$; beyond this threshold, household assets, incomes, and farm productivity decline sharply. The use of purchased inputs per land unit, a measure of land intensification, is also found to decline beyond roughly 600 persons per $\mathrm{km}^{2}$. Currently $14 \%$ of Kenya's rural population resides in areas exceeding this population density. Another $20 \%$ of the rural population residing in the 3 rd population density quintile is approaching this limit.

\footnotetext{
${ }^{9}$ Namwaya (2004) reports that over 600,000 ha of land, or roughly one-sixth of Kenya's total land area, are held by the families of the country's three former presidents, and that most of this land is in relatively high-potential areas.
}

Higher population density is also found to be associated with smaller farm sizes and decreased fallow land, other factors constant. Small farm sizes may be associated with diseconomies of scale in input acquisition. Smaller farm sizes also lower levels of surplus farm production, which in turn is likely to exacerbate households' capital constraints and depress their demand for purchased inputs and new technologies. These processes may explain why our results indicate adverse effects of population density, beyond some threshold, on indicators of farm intensification, farm income per unit of labor, and household wealth per adult equivalent.

Declining labor productivity in an environment of high labor-to-land ratios also provides incentives for labor migration to off-farm activities. This is consistent with our earlier descriptive findings of higher rates of adults leaving the panel households over the 1997-2010 period in the villages of high population density areas compared those of low population density.

Average landholding sizes of the survey respondents' parents were found to be three to four times larger than for the survey respondents themselves. Now that farm sizes are below 1.2 ha on average in Kenya's high density rural areas, it is difficult to envision how the current generation of farm households will be able to further subdivide their land among their children or how they will be able to farm a sufficient amount of land to sustain even current levels of farm income without major improvements in farm technologies and productivity.

These findings brings to the fore one of the first implications for public institutions, i.e., the need for redoubled public investment in the national agricultural research and extension systems to focus on new farm technologies and practices appropriate for one-hectare farms or smaller. These technologies need to be land-saving. While improved land productivity can improve small farm livelihoods and food security in densely populated areas, this alone is unlikely to be a panacea for addressing Kenya's emerging land and rural livelihoods problems.

This brings us to the study's third and final objective, exploring the implications of Kenya's land problem for institutions and policies in Kenya. Since independence, successive Kenyan governments have acknowledged the semi-landless conditions of many rural households in Kenya but so far the rhetoric has mainly been to condemn the historical wrongs of the colonial era while redistributing former colonial farms and state lands to political elites (Okoth-Ogendo 1976, 1999; Kanyinga 1998; Juma 1996; Platteau 2004). This has led commentators such as John Mbaria to warn that "we have adopted an attitude of burying our heads in the sand and may not do anything until the looming land crisis degenerates into Zimbabwe-like chaos" (Mbaria 2001). The National Land Policy Formulation paper of 2004 admits that Kenya does not have a clearly defined land policy and as a result, "important issues such as land administration, access to land, land use 
planning, restitution of historical injustices, environmental concerns, plot allocations ... are inadequately addressed." In the interim, rural Kenyans live with massive loss of public lands through irregular but often technically legal disposal by the Government, including quite recently to foreign investors (Republic of Kenya 2004).

Assessing land policy across the continent, Wily (2011) concludes that "land reformism in Africa since the 1990s has simply failed to give precedence to majority customary land rights over and above state and investor claims for these same lands. In light of this, it is difficult to see the current wave of large-scale land acquisitions by local and foreign investors as other than a reflection of already weak political will to fully reform land tenure relations in favor of the majority poor.... therefore the current land rush for large-scale lands for commercial food and biofuel production is not the cause of this insecurity: rather, it brings existing insecurity of tenure to the fore" (p. 59).

The new Kenyan Constitution promulgated in August 2010 through Article 67 establishes a National Land Commission (NLC) that will, among other things, conduct investigations into "historical land injustices" and recommend appropriate redress (Republic of Kenya 2010). Article 68 requires Parliament to enact a law that will "enable the review of all grants or dispositions of public land to establish their propriety or legality". The new constitution also confers on Parliament the responsibility to prescribe the minimum and maximum land holding acreages in respect of private land and to regulate the manner in which any land may be converted from one category to another. However, with declining farm sizes and fragmentations occurring along with some technical innovation, the question of defining what constitutes a viable farm unit remains an elusive task.

Given the existing distribution of landholdings within Kenya's small farm sector, strategies to improve rural households' access to land will need to be not only on the country's land agenda, but also its food security and poverty reduction agendas. As the land frontier closes in many parts of Kenya and population continues to rise, smallholder farming areas will be producing fewer food surpluses in the future unless there is major productivity growth through technical innovation. Many of these areas will become food deficit more quickly after harvest and resemble urban areas in that they will be a source of food demand rather than food supply. Being a food importer, Kenya's food prices approximate import parity levels and make both the urban and rural poor vulnerable to the vagaries of international food markets unless the government embarks on the expensive option of attempting to shield consumers from world markets. In this evolving scenario, the most fundamental food security policy questions involve how to enable smallholder farmers to gain access to productive resources and how to improve the productivity of their scarce resources so that they are capable of producing a meaningful farm surplus in the first place.

There is also some scope for promoting equitable access to land through a coordinated strategy of public goods and services investments to raise the economic value of arable land in the country that is relatively remote and still unutilized. This would involve investments in road infrastructure, schools, health care facilities, electrification and water supply, and other public goods required to induce migration, settlement, and investment in these currently under-utilized areas. Through migration, such investments would also help to reduce population pressures in the densely populated areas, many of which are being degraded due to declining fallows associated with population pressure. The approach of raising the economic value of land through public investments in physical infrastructure and service provision was successfully pursued by Southern Rhodesia/Zimbabwe starting in the 1970s with its "growth point" strategy in the Gokwe area, once cleared of tse tse flies. Key public investments in this once desolate but agro-ecologically productive area induced rapid migration into Gokwe from heavily populated rural areas, leading to the "white gold rush" of smallholder cotton production in the 1980s (Govereh 1999). A second and complementary approach would be to institute more transparent and orderly procedures for the allocation of state land (Munshifwa 2002; Stambuli 2002).

Kenya's new National Land Commission will not be the country's first attempt to address the country's growing land problem. There are signs that the severity of the land problem is widely recognized. But a strong case could be made that unless the current attempts at land policy reform can succeed in providing substantially greater access to land for smallscale agriculture-led development, the prospects for structural transformation, rural poverty reduction, and even political stability will be in jeopardy.

Acknowledgements This paper has been prepared under the Guiding Investments in Sustainable Agricultural Markets in Africa (GISAMA), a grant from the Bill and Melinda Gates Foundation to Michigan State University's Department of Agricultural, Food, and Resource Economics. The authors also acknowledge the long-term support that the United States Agency for International Development (USAID) Kenya has provided to the Tegemeo Institute of Egerton University for the collection of panel survey data over the 10 -year period on which this study draws. They also wish to thank Margaret Beaver for her assistance in cleaning the data and generating the variables of interest as well as Steven Longabaugh and Jordan Chamberlin for their assistance with several figures used in this article. Any errors and omissions are those of the authors only. The views expressed in the article do not necessarily reflect the views of the Bill and Melinda Gates Foundation, USAID, or any other organaization.

Open Access This article is distributed under the terms of the Creative Commons Attribution License which permits any use, distribution, and reproduction in any medium, provided the original author(s) and the source are credited. 


\section{References}

Barrett, C. B. (2008). Smallholder market participation: concepts and evidence from Eastern and Southern Africa. Food Policy, 33(4), 299-317.

Binswanger, H., \& Ruttan, V. (1978). Induced innovation: technology, institutions and development. Baltimore: Johns Hopkins University Press.

Binswanger, H., \& McIntire, J. (1987). Behavioral and material determinants of production relations in land-abundant tropical agriculture. Economic Development and Cultural Change, 36(1), 73-99.

Binswanger, H., \& Pingali, P. (1988). Technological priorities for farming in Sub-Saharan Africa. World Bank Research Observer, $3(1), 81-98$.

Boserup, E. (1965). The conditions of agricultural growth: The economics of agrarian change under population pressure. London: Allen \& Unwin.

Carter, M. R., \& Barrett, C. (2006). The economics of poverty traps and persistent poverty: an asset based approach. Journal of Development Studies, 42(2), 178-199.

Chamberlain, G. (1984). Panel data. In Z. Grilliches and M. D. Intriligator (Eds.), Handbook of econometrics, vol. 2, (pp. 1247-1318). North Holland, Amsterdam.

Deininger, K., \& Binswanger, H. (1995). Rent seeking and the development of large-scale agriculture in Kenya, South Africa, and Zimbabwe. Economic Development and Cultural Change, 43(3), 493-522.

Deininger, K., \& Byerlee, D., with Lindsay, J., Norton, A., Selod, H., \& Stickler, M. (2011). Rising global interest in Farmland. Report. The World Bank, Washington D.C.

Govereh, J. (1999). Impacts of tsetse control on immigration and household accumulation of capital: Zambezi Valley, Zimbabwe. East Lansing: Michigan State University. PhD Dissertation.

Hayami, Y., \& Ruttan, V. (1971). Agricultural development: An international perspective. Baltimore: Johns Hopkins Press.

Johnston, B. F., \& Kilby, P. (1975). Agriculture and structural transformation: Economic strategies in late developing countries. New York: Oxford University Press.

Juma, C. (1996). Introduction. In C. In Juma \& J. B. Ojwang (Eds.), Land we trust: environment, private property and constitutional change. African Centre for Technology Studies (ACTS) environmental policy series: 7 (pp. 1-5). Nairobi: Initiatives Publishers.

Jayne, T. S., Yamano, T., Weber, M., Tschirley, D., Benfica, R., Chapoto, A., \& Zulu, B. (2003). Smallholder income and land distribution in Africa: implications for poverty reduction strategies. Food Policy, 28(3), 253-275.

Jayne, T. S., Zulu, B., Kajoba, G., \& Weber, M. (2009). Access to land, and poverty reduction in rural Zambia: Connecting the policy issues. Working Paper 34. Food Security Research Project, Lusaka, Zambia.

Kanyinga, K. (1998). Politics and struggles of access to land: 'Grants from above' and 'squatters' in Coastal Kenya. European Journal of Development Research, 10(2), pages.

Krishna, A., Kristjanson, P., Radeny, M., \& Nindo, W. (2004). Escaping poverty and becoming poor in twenty Kenyan Villages. Journal of Human Development, 5(2), 211-226.
Mbaria, J. (2001). We ignore land issues at our peril, The Daily Nation, 16 August 2001, Nairobi.

Mellor, J. (1976). The new economics of growth. Ithaca: Cornell University Press.

Mundlak, Y. (1978). On the pooling of time series and cross section data. Econometrica, 46, 69-85.

Munshifwa, E. (2002). Rural land management and productivity in Rural Zambia: The need for institutional and land tenure reforms. Paper presented at the Surveyor's Institute of Zambia Seminar, July 2002, Oxfam.

Namwaya, O. (2004). Who owns Kenya? East Africa standard, October 1, 2004. http://www.marsgroupkenya.org/pdfs/crisis/ 2008/02/large_landowners_in_Kenya.pdf.

Okoth-Ogendo, H. W. O. (1976). African land tenure reform. In H. Judith, J. K. Maitha, \& W. M. Senga (Eds.), Agricultural development in Kenya and economic assessment (pp. 152185). Nairobi: Oxford University Press.

Okoth-Ogendo, H. W. O. (1999). Land Policy development in East Africa, a survey of recent trends. A regional overview paper for the DFID workshop on "Land rights and sustainable development in Sub-Saharan Africa" held at Sunningdale Park conference centre, Berkshire, England, (pp. 16-19) February, 1999.

Platteau, J. (2004). Monitoring elite capture in community-driven development. Development and Change, 35, 223-246.

Pingali, P. L., \& Binswanger, H. (1988). Population density and farming systems - the changing locus of innovations and technical change. In R. Lee (Ed.), Population, food and rural development. Oxford: Clarendon.

Republic of Kenya. (1965). The sessional paper no. 10 of 1965 on African socialism and its application to planning in Kenya. Nairobi: Government Printer.

Republic of Kenya. (2004). Report of the commission of inquiry into illegal/irregular allocation of public land, June 2004. Nairobi: Government Printer.

Republic of Kenya. (2010). Constitution of Kenya. Nairobi: Government Printer.

Stambuli, K. (2002). Elitist food and agricultural policies and the food problem in Malawi. Journal of Malawi Society-Historical \& Scientific, 55(2).

Wily, L. A. (2011). The tragedy of public lands: The fate of the commons under global commercial pressure. Report for International Land Coalition, IFAD, Rome. http://www.landcoalition.org/sites/default/ files/publication/901/WILY_Commons_web_11.03.11.pdf. Accessed 30 October 2011.

Woodhouse, P. (2003). African enclosures: a default mode of development. World Development, 31(10), 1705-1720.

Wooldridge, J. M. (2010). Econometric analysis of cross section and panel data (2nd ed.). London: MIT Press.

World Bank. (2008). World development report 2008: Agriculture for development. Washington, DC: World Bank.

Yamano, T., Place, F., Nyangena, W., Wanjiku, J., \& Otsuka, K. (2009). Efficiency and equity impacts of land markets in Kenya. Chapter 5. In S. T. Holden, K. Otsuka, \& F. M. Place (Eds.), The emergence of land markets in Africa. Washington, DC: Resources for the future. 


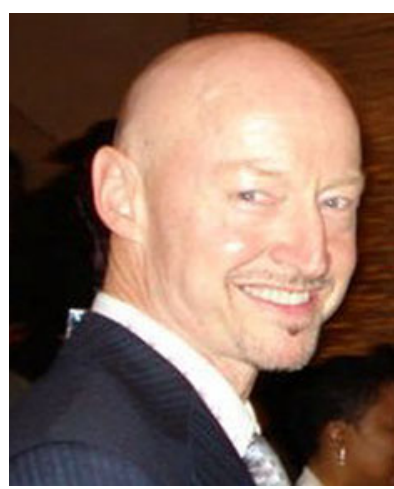

T. S. Jayne Professor, International Development, in the Department of Agricultural, Food, and Resource Economics at Michigan State University. His main research focus is on how agricultural policies and public investments can contribute to sustainable and equitable development. He has collaborated with Egerton University's Tegemeo Institute on agricultural policy issues in Kenya since its inception in 1996. Jayne sits on the editorial boards of two development journals, co-authored a paper (with graduate student Jacob Ricker-Gilbert) awarded the T.W. Schultz Award at the 2009 International Association of Agricultural Economists Triennial Meetings, received the 2009 Best Article Award in Agricultural Economics, and co-authored a paper awarded First Prize at the 2010 triannual meetings of the Association of African Agricultural Economists.

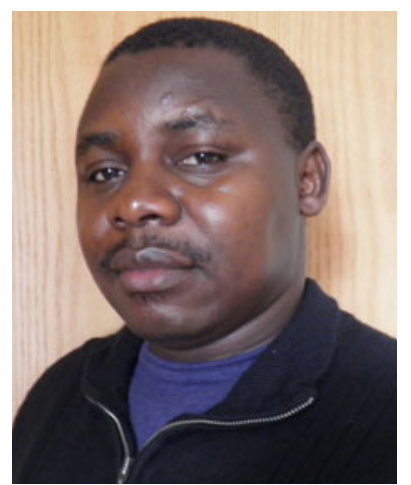

Milu Muyanga Research fellow at Tegemeo Institute (Egerton University) and currently $\mathrm{Ph} . \mathrm{D}$. candidate at Michigan State University. He holds both Master and Bachelor of Arts degrees in economics from the University of Nairobi. His areas of interests include but are not limited to agricultural markets and prices analysis; rural development and livelihoods analysis; and agricultural programs/projects monitoring and impact evaluation. Until 2004, he worked as an economist in the Ministry of Finance and Planning in the Government of Kenya. Milu was the first prize winner of the 2007 Global Development Network's medal for the best research on household exposure to risk theme. 